\title{
To Guide or Not to Guide? Quantitative Monetary Policy Tools and Macroeconomic Dynamics in China*
}

\author{
Hongyi Chen, ${ }^{\text {a,b }}$ Michael Funke, ${ }^{c, d}$ Ivan Lozev, ${ }^{\mathrm{e}}$ \\ and Andrew Tsang ${ }^{\mathrm{c}}$ \\ ${ }^{a}$ Hong Kong Institute for Monetary and Financial Research \\ ${ }^{\mathrm{b}}$ Hong Kong Monetary Authority \\ ${ }^{\mathrm{c}}$ Hamburg University \\ d Tallinn University of Technology \\ ${ }^{\mathrm{e}}$ European Commission
}

This paper discusses the macroeconomic effects of China's quantity-based banking regulatory tool, "window guidance," introduced in 1998. Using an open-economy DSGE model that includes a commercial banking sector, we study the stabilizing effects of this nonstandard quantitative monetary policy tool and the implications of quantity-based versus price-based monetary policy instruments for welfare. The analyses are relevant to the current overhaul of Chinese monetary policy.

JEL Codes: C61, E32, E44, E52.

\section{Introduction}

China's monetary policy has been in flux in recent years. Broadly speaking, the central bank embraced a gradual switch from quantitybased measures to guide monetary policy toward a price-based

*The authors thank two anonymous referees and the associate editor for helpful comments on an earlier draft and encouragement. The paper has also benefitted from seminar and workshop participants at the Bank of Finland, the Hong Kong Monetary Authority, the Chinese University of Hong Kong, the University of Western Australia, and the University of Hamburg. The views expressed in this paper are those of the authors and do not necessarily reflect those of the Hong Kong Monetary Authority. Any remaining errors are our own. Author e-mails: hchen@hkma.gov.hk; michael.funke@uni-hamburg.de or michael.funke@taltech.ee; ivan.lozev@ec.europa.eu; heung.chun.tsang@unihamburg.de. 
approach that gave more weight to interest rates and let liquidity levels be determined by the price, rather than volume, of capital. The change was intended to bring the People's Bank of China (PBoC) closer to the practices of its counterparts in advanced economies.

Since China is transitioning to a price-based monetary policy approach, the future roles of China's administrative and quantitybased monetary policy tools are an open question 11 In the past, China's monetary policy has been predominantly quantitative in nature, and the use of quantitative tools has long been the norm in implementing China's monetary policy. In particular, the $\mathrm{PBoC}$ has relied on "lending quotas" known as "window guidance" to influence bank behavior. The origin of window guidance dates back to 1998 when the $\mathrm{PBoC}$ abolished its pure quantity-based credit plan, a direct control on the credit quantity of state-owned banks. Window guidance is formulated by the $\mathrm{PBoC}$ and uses moral suasion to get banks and other financial institutions to follow official $\mathrm{PBoC}$ lending guidelines. The lending guidance is communicated in regular monthly meetings with commercial banks. The window guidance policy tool primarily targets the big-four state-owned banks, but it also extends to joint-stock commercial banks and smaller local banks. What's more, in addition to aggregate/across-the-board quantitative guidance, the $\mathrm{PBoC}$ on occasion tries to steer lending to particular sectors of the economy. For example, the $\mathrm{PBoC}$ might impose limits on property-related loans or promote lending to preferred sectors such as small and medium-sized enterprises. In the past, window guidance has been regarded by observers as one of the PBOC's most effective policy tools (e.g., Fukumoto et al. 2010, Lardy 2005). Some of the success of window guidance in China can be attributed to Chinese political hierarchic structures. The governor of the $\mathrm{PBoC}$ ranks higher in the political pecking order than heads of the state-owned commercial banks.

This raises the question of what role window guidance should play in the future. The Chinese government's statements in this

\footnotetext{
${ }^{1}$ For a review of the current overhaul of Chinese monetary policy and the next steps in transitioning to a modern and market-based monetary framework, see, e.g., Chen, Ren, and Zha (2018), He, Wang, and Yu (2015), Fernald, Spiegel, and Swanson (2014), and International Monetary Fund (2017b, pp. 34-40).
} 
respect are inconclusive. It pledges to let markets play a decisive role in the economy, but the desire for more efficient allocation of capital clashes with the authority's reflexive instinct for control to prevent a slowdown in growth. Thus, the tension between reform and control is quite evident in China's current monetary policy overhaul. Against this background, we analyze the efficacy of window guidance in a calibrated dynamic stochastic general equilibrium (DSGE) framework. Chang et al. (2016), Dai, Minford, and Zhou (2015), Le et al. (2014), and Liu, Wang, and Xu (2017) have recently modeled China's monetary policy in DSGE models. However, none of these papers has addressed window guidance policy in the theoretical framework. We strive to close this gap with the present paper. To our knowledge, it is the first paper to provide an in-depth DSGE-based assessment of window guidance allowing insights into Chinese-style monetary policy transmission channels. We also evaluate the welfare implications of introducing window guidance as an additional monetary policy tool.

In the modeling framework, particular attention will be paid to the problem of eroding policy buffers. The erosion of policy buffers during the global financial crisis in many countries has made it more difficult to curtail the slowdown in growth through monetary stimulus. As this problem persisted, monetary policymakers increasingly contemplated radical approaches to pull their economies out of zero lower bound quicksand. In this spirit, we assess window guidance as a nonstandard policy tool for an economy subject to rare, but highly damaging, disruptions and investigate its effects. We are thus addressing Blanchard's (2014) warning of "dark corners." This makes it possible to answer the question of whether the $\mathrm{PBoC}$ should retain the nonstandard window guidance toolkit to address situations in which the economy is in rare "bad" states and the $\mathrm{PBoC}$ is limited in the use of its policy interest rate.

The remainder of the paper is as follows. Section 2 presents descriptive evidence about China's window guidance policy. In section 3, a DSGE model with window guidance is presented. To give a sense of the magnitudes, section 4 calibrates the model and provides a set of numerical experiments. Section 5 discusses the pros and cons of window guidance from an international point of view. Section 6 concludes. 


\section{Window Guidance and Financial Intermediation in China}

Following the narrative approach of Romer and Romer (1989, 2004), we summarize the episode-by-episode development of the PBoC's window guidance policy with the corresponding economic situation at that moment. This approach relies on the reading of the central bank's documents to infer additional information on the PBoC's intentions. The policy stance is identified and, in addition, the driving force of each policy movement is detected 2 We study all issues of the "Quarterly Monetary Policy Report" (QMPR) from 2001 onward and construct an indicator for the window guidance policy stance. 3

The PBoC's window guidance policy can be classified into five stances. Table 1 presents definitions of indicators corresponding to five different stances of window guidance. Online appendix A (available at http://www.ijcb.org) gives a quarter-by-quarter summary of stances of $\mathrm{PBoC}$ window guidance policy from the QMPR.

Our method of distilling the window guidance information contained in the $\mathrm{PBoC}$ publications gives the following timeline of the window guidance policy stance:

- 1998-2000: The PBoC started to implement window guidance in 1998 in the wake of the Asian Financial Crisis. The PBoC sought to boost the economic growth by stimulating the supply of bank credit through an "encouraging" window guidance policy. The $\mathrm{PBoC}$ cautioned banks, however, about real estate lending; see Zhang and Ji (2012).

- 2001-02: The PBoC gave "no explicit direction" on window guidance during this period.

\footnotetext{
${ }^{2}$ Angrick and Yoshino (2018) have recently combined the narrative approach with computational linguistic methods to quantify the stance of window guidance.

${ }^{3}$ The quarterly publication has been released since 2001:Q1. Its purpose is to increase policy transparency and enhance communication with the general public. For the purposes of this discussion, the useful feature is that the $\mathrm{PBoC}$ has commented consistently on window guidance since 2001:Q4. When evaluating the $\mathrm{PBoC}$ reports, we have paid particular attention to a careful demarcation of window guidance statements from wider governmental policy objectives.
} 


\section{Table 1. Qualitative Window Guidance Policy Stances (1998:Q1-2016:Q2)}

\begin{tabular}{|c|c|c|c|}
\hline Indicator & Stance & Period & Definition \\
\hline \multirow[t]{2}{*}{-2} & Strongly & 2003:Q1-2004:Q4 & QMPR explicitly discourages \\
\hline & Discouraging & 2006:Q2-2008:Q2 & growth of total credit. \\
\hline \multirow[t]{2}{*}{-1} & Weakly & 2005:Q1-2006:Q1 & QMPR states the target of \\
\hline & Discouraging & 2010:Q2-2012:Q2 & $\begin{array}{l}\text { optimizing credit structure, } \\
\text { provides risk alerts, and/or } \\
\text { mentions that banks should } \\
\text { manage the pace of credit } \\
\text { growth. }\end{array}$ \\
\hline \multirow[t]{2}{*}{0} & No Explicit & 2001:Q1-2002:Q4 & QMPR only states the target \\
\hline & Direction & 2012:Q3-2014:Q2 & $\begin{array}{l}\text { of optimizing credit } \\
\text { structure and separately } \\
\text { listing the sectors that } \\
\text { should be both discouraging } \\
\text { and encouraging } \\
\text { (differentiated approach to } \\
\text { credit guidance) or no } \\
\text { explicit direction of credit } \\
\text { growth. }\end{array}$ \\
\hline 1 & $\begin{array}{l}\text { Weakly } \\
\text { Encouraging }\end{array}$ & 2014:Q3-2016:Q2 & $\begin{array}{l}\text { QMPR only lists sectors to be } \\
\text { encouraged for the target of } \\
\text { optimizing credit structure. }\end{array}$ \\
\hline 2 & Strongly & 1998:Q1-2000:Q4 & QMPR encourages the \\
\hline & Encouraging & 2008:Q3-2009:Q1 & $\begin{array}{l}\text { growth of total credit } \\
\text { explicitly. }\end{array}$ \\
\hline
\end{tabular}

- 2003-08: The PBoC strengthened window guidance to curb accelerated growth in lending, particularly to the real estate sector. During this period, the PBoC expressed a "strongly discouraging" window guidance stance to cool credit growth (2003-04 and 2006 to mid-2008), and a "weakly discouraging" stance in 2005, when the $\mathrm{PBoC}$ guided banks to optimize the credit structure in light of falling consumer price index (CPI) inflation.

- 2008-09: The onset of the global financial crisis in September 2008 adversely affected the Chinese economy. Facing 
rapidly deteriorating economic growth, Chinese authorities introduced a 4-trillion-yuan stimulus plan, while the $\mathrm{PBoC}$ simultaneously removed all rigid constraints on commercial bank lending and adopted a window guidance policy that "strongly encouraged" banks to provide loans in the last quarter of 2008. The policy continued through mid-2009.

- 2009-10: Surging bank lending, particularly to real estate investment, alerted the Chinese authorities to an emerging risk of overheating. The $\mathrm{PBoC}$ responded with a sharp policy reversal on window guidance to "strongly discourage" lending. It emphasized the role of banks in risk prevention and controling credit growth.

- 2010-12: As credit growth gradually slowed in early 2010, the $\mathrm{PBoC}$ assumed a "weakly discouraging" window guidance stance. The PBoC encouraged banks to manage the pace and structure of credit supply and sought to discourage lending in overcapacity sectors.

- 2012-14: While a production growth slowdown and overcapacity concerns prevented the $\mathrm{PBoC}$ from stating an explicit direction for credit growth under its window guidance stance, it was able to emphasize loan reallocation. Specifically, it said its target now was optimizing the credit structure and focused window guidance by sector. A "discouraging" stance was recommended for overcapacity sectors and an "encouraging" stance for policy sectors. The period marked the beginning of an era in which the $\mathrm{PBoC}$ emphasized the loan reallocation function of window guidance.

- 2014-16: As economic growth slowed, the PBoC "encouraged" banks to lend more. The nuanced response of sector focus meant, however, that overcapacity sectors still received differentiated treatment and one-size-fits-all measures were eliminated.

Figure 1 shows four selected macroeconomic variables overlaid with the time-varying window guidance stance. (For figures in color, see the online version at http://www.ijcb.org.) The shifting intensity and focus of the window guidance policy stance reflects the business cycle in terms of the output gap, the change in the output gap, CPI inflation, and loan growth. The graphical evidence illustrates 


\section{Figure 1. Window Guidance Stance, Output Gap, CPI Inflation, and Loans}

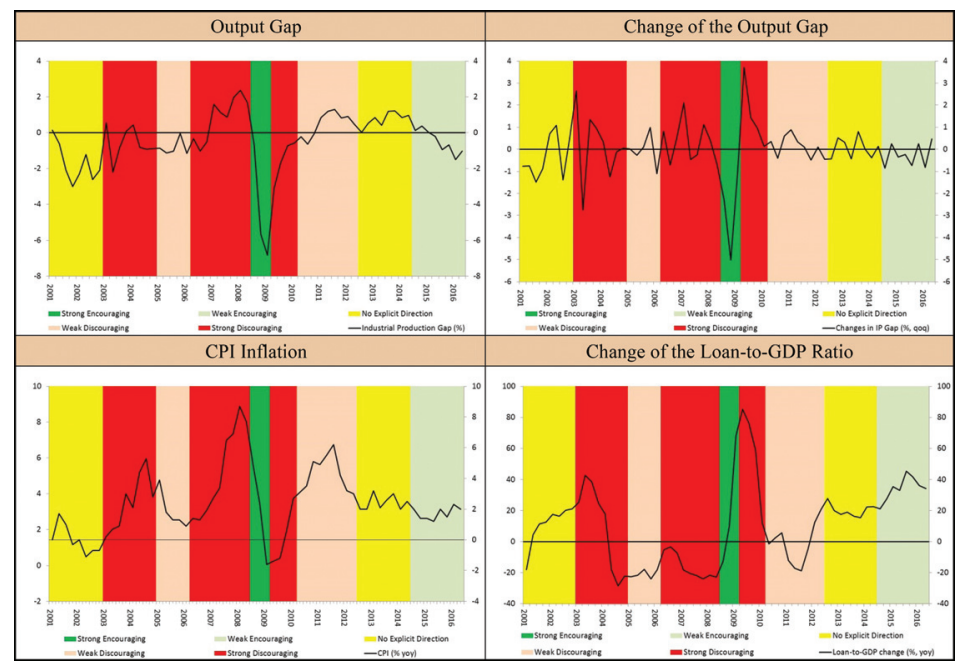

Sources: Authors' calculations based on information from $\mathrm{PBoC}$ and National Statistical Bureau of China.

Notes: The definitions of the quarterly variables are descibed in online appendix B. Here, we use the industrial-production-based output gap instead of the GDPbased output gap, because, at least in our view, the PBoC's loan-related policies have tended to focus mainly on industrial output growth.

that the window guidance stance is indeed countercyclical and thus aligned with the business cycle.

Summarizing the above, it can be said that window guidance is a prominent quantity-based monetary instrument to the present day. It is repeatedly emphasized in the PBoC's monetary policy reports. How is the window guidance policy stance coordinated with other monetary policy instruments? Figure 2 shows the systematic pattern between window guidance and other monetary policy tools. When the window guidance stance is "encouraging," interest rates decrease, and vice versa. Furthermore, the PBoC usually raises the required reserve ratio during the period when the window guidance stance is "discouraging," and vice versa 4 In other words, the pricebased and quantity-based instruments are mutually coordinated.

\footnotetext{
${ }^{4}$ Traditionally, the $\mathrm{PBoC}$ has steered reserve requirements to sterilize liquidity injections and withdrawals related to its interventions in the foreign exchange
} 


\section{Figure 2. Coordination between Window Guidance and Price-Based Monetary Policy Tools}

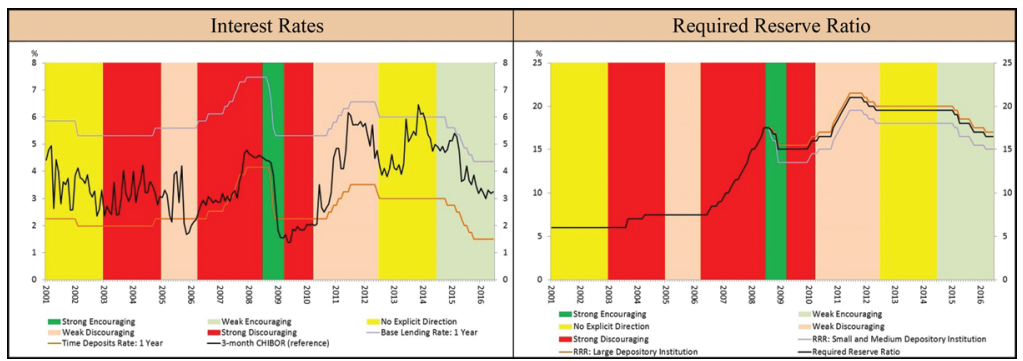

Sources: PBoC, CEIC, and authors' calculations.

It should be noted that we regard the evidence presented above as more descriptive than a rigorous statistical pursuit. In particular, we have so far not acknowledged the fact that the window guidance stance evolves endogenously with the state of the economy. Not only may the $\mathrm{PBoC}$ respond to incoming news about output and inflation by changing its policy stance, but shifts in its policy stance can also affect agents' expectations about the future evolution of the economy. Without isolating this systematic component of monetary policy, it is difficult to infer anything about the effectiveness of window guidance. In order to separate the "surprise" window guidance component from the "expected" window guidance component, one needs to control for the variation in economic fundamentals that the policy endogenously responds to. To do so we estimate the forward-looking Taylor rule $S_{t}=c+\beta_{S} S_{t-1}+\beta_{\pi} \pi_{t+1}^{e}+\beta_{g a p} g a p_{t+1}^{e}+\varepsilon_{t}$, where $S_{t}$ is the the window guidance stance, $\pi_{t+1}^{e}$ is the inflation expectation in the next period (proxied by the one-step-ahead $\mathrm{AR}(1)$ forecasts), $g a p_{t+1}^{e}$ is the industrial production-based output gap forecast for the next period (proxied by the one-step-ahead $\mathrm{AR}(1)$ forecasts), and $\varepsilon_{t}$ is the error term. Then, the window guidance shocks can be calculated as $\hat{\varepsilon}=S_{t}-\hat{c}-\hat{\beta}_{S} S_{t-1}-\hat{\beta}_{\pi} \pi_{t+1}^{e}-\hat{\beta}_{g a p} g a p_{t+1}^{e} 5$ What

markets. For this reason, we omit the reserve requirement rate as a monetary policy tool from our closed-economy DSGE framework.

${ }^{5}$ In constructing the five-value window guidance policy stance variable and window guidance policy shock indicator, we would like to point out that, like 


\section{Table 2. The Correlation Coefficient of the Window Guidance Shock $\hat{\varepsilon}_{t}$ and Economic Variables}

\begin{tabular}{|l|c|}
\hline Variables & $\begin{array}{c}\text { Correlation } \\
\text { Coefficient }\end{array}$ \\
\hline Output Gap & -0.1467 \\
$\Delta$ Output Gap & -0.5507 \\
CPI Inflation & -0.0325 \\
$\Delta$ Loan-to-GDP Ratio & -0.0666 \\
\hline \multicolumn{2}{|c|}{ Sources: Authors' calculations based on information from PBoC and National Sta- } \\
tistical Bureau of China. \\
Note: The definitions of variables are described in online appendix B. \\
\hline
\end{tabular}

is the relationship between the two indicators $S_{t}$ and $\hat{\varepsilon}_{t}$ ? The correlation coefficient and the rank correlation coefficient of $S_{t}$ and $\hat{\varepsilon}_{t}$ are 0.623 and 0.806 , respectively. In addition, the graph in online appendix $\mathrm{C}$ shows that in the change of each regime (stance), there is a jump and otherwise $\hat{\varepsilon}_{t}$ is roughly zero. This is confirmed by the bivariate Granger causality tests in online appendix D, which find unidirectional Granger causality from $\hat{\varepsilon}_{t}$ to $S_{t}$. Finally, the correlation coefficients of $\hat{\varepsilon}_{t}$ with the economic variables given in table 2 . As expected, the results show that the $\mathrm{PBoC}$ employs window guidance policy in a countercyclical manner.

It is important to emphasize that providing a precise quantification of the role of window guidance shocks is an inherently difficult task. The bivariate correlations in table 2 focus only on part of a complex web of relationships. This comes with the caveat that other factors may simultaneously affect loans and output. Not taking these into account may lead to an upward bias in the estimated role of window guidance and loans in predicting the industrial production dynamics. As a robustness check, we have therefore also calculated four-variable VARs 6 We find that the window guidance

many other researchers, we need to measure and analyze concepts using an ordinal scale. Recent research by Schroder and Yitzhaki (2017) shows that, in theory, the cardinal statistical treatment of ordinal variables must be robust to increasing monotonic transformations of the ordinal scale. In headline terms, we find that the econometric results are largely robust to reasonable data transformations.

${ }^{6}$ The associated impulse response functions are available in online appendix E. 
shock measure $\hat{\varepsilon}_{t}$ has incremental forecasting power for loans. Furthermore, loans have a significant influence on the development of inflation and the output gap. Conversely, there is no significant feedback from loans to the window guidance shock. Overall it appears that the PBoC's attempt at policy via suasion was successful. This result provides a rigorous statistical justification for the inclusion of nonstandard window guidance policies in our framework.

Finally, two China-specific aspects warrant a brief discussion. Chen, Ren, and Zha (2018) and Hachem and Song (2016) have recently highlighted the institutional asymmetry between stateowned and non-state-owned banks in China. For this reason, further information about the transmission channel of window guidance is provided in online appendix $\mathrm{F}$ showing the loans from the four major state-owned banks (the Bank of China, the China Construction Bank, the Agricultural Bank of China, and the Industrial and Commercial Bank of China) versus other banks. As expected, the general impression is that the state-owned banks are by and large more compliant with the window guidance policies than private banks. Nevertheless, both loans series point in the same direction. Another potentially important question is whether the impact of window guidance is the same for state-owned and non-state-owned firms. Figure G.1 in online appendix $\mathrm{G}$ indicates that the time-varying loan dynamics is broadly similar across state-owned and non-state-owned firms. However, the response for state-owned firms is more pronounced. In other words, to some degree an asymmetric impact exists which may exacerbate inefficiencies in resource allocation.7

While a descriptive empirical exploration of the application and efficacy of window guidance gives a sense of the transmission channels of window guidance, it does not provide evidence on specific effects from a window guidance stance. Isolating the effect of window guidance from complementary policies or other economic developments constitutes a significant empirical challenge and requires cautious interpretation. To address this difficulty, a large strand of

\footnotetext{
${ }^{7}$ Chang et al. (2016) study the role of reserve requirements for China's macroeconomic stabilization in a two-sector DSGE model with state-owned enterprises (SOEs) and private-owned enterprises (POEs) having access to segmented credit markets. On this topic also see Buera, Kaboski, and Shin (2011), Hsieh and Klenow (2009), and Song, Stroesletten, and Zilibotti (2011).
} 
literature on the impact of monetary policy employs New Keynesian general equilibrium DSGE modeling toolkits. In this tradition, we offer a structural interpretation of window guidance policy through the lens of a DSGE model for mainland China.

\section{The DSGE Modeling Framework}

To place monetary policy discussions in China in a coherent conceptual framework, we develop a DSGE framework that considers China's unique monetary transmission characteristics. The model is designed to be tractable to obtain intuitive results.

A large body of theoretical literature has arisen in recent years on incorporating financial features and the banking sector into DSGE models. In the strand represented by Gerali et al. (2010), the model economy features patient and impatient households, as well as entrepreneurs. Impatient households and entrepreneurs are collaterally constrained. Interest rates are set optimally by banks subject to quadratic adjustment costs, which makes their pricing decisions intertemporal. Here, we extend Gerali et al. (2010) by modeling a "semi-open" economy (Jeanne 2013). We assume world interest rates do not respond to Chinese economic conditions. Only tradables are produced and purchased both domestically and abroad. Both consumption and investment goods can be imported from abroad. The ratio of domestic and imported goods in the consumption and investment bundles depends on the relative prices. Despite baby steps toward liberalization, the Chinese capital account remains largely closed (e.g., private entities are not free to hold assets denominated in foreign currency). Instead, foreign assets, accumulated from positive current account balance, are exchanged for securities denominated in local currency by the $\mathrm{PBoC} 8 \mathrm{Tw}$ wo consequences arise from

\footnotetext{
${ }^{8}$ As a semi-open economy, the public sector in China has access to the international financial markets whereas the private sector cannot freely hold foreign assets. The Chinese government has recently sought to liberalize the country's capital account. Part of this effort includes the rollout of investment vehicles for foreigners wanting to invest in China and Chinese firms exploring overseas opportunities. While these measures represent incremental liberalizations of China's capital account, the pace of change has been slow. Extensive capital controls remain intact, limiting room for speculative maneuvering.
} 
this arrangement. First, nominal exchange rate fluctuations, as well as any misalignment between foreign and domestic interest rates, are not reflected in the budget constraint of private agents - but they do affect the PBoC's profit/loss position. Second, the standard uncovered interest rate parity (UIP) may not hold in equilibrium, because arbitrage between domestic and foreign assets is administratively prohibited. The UIP condition is replaced by an equation that allows exchange rate to reflect only a small fraction of the ex ante spreads between the returns of domestic and foreign assets. This arrangment stabilizes exchange rate movements and nests two extreme cases - fully open and fully closed capital accounts. Several alternative microfounded setups may give rise to such a "distorted" no-arbitrage rule. Chang, Liu, and Spiegel (2015) model China's capital controls as a quadratic friction on the deviation of investor's portfolio choice between domestic bonds and foreign assets from an exogenous benchmark. If, instead, the cost of holding foreign bonds depends on the spread between return on domestic and return on foreign bonds, the modified UIP condition will take the same form as the one declared below. The same equation may be derived from an equilibrium in the foreign exchange market, whereas only a small fraction of participants are allowed to exchange foreign assets. The aggregate link between the ratio of foreign and domestic interest rates and nominal exchange rate would be proportional to the share of arbitrageurs in the market. Yet a third rationalization of the modified UIP condition may involve the PBoC's strategy to adjust the exchange rate very gradually, taking into account the difference between domestic and foreign bond return.

Crucially to our analysis, we expand the model of Gerali et al. (2010) by introducing occasionally binding constraints on credit activity. We implement this feature by augmenting the Euler equation of retail banks with a Lagrange multiplier that is positive when the constraint binds. This alters the optimal path of lending rates, and the effect is propagated through the economy. Gerali et al. (2010) feature multiple rigidities in factor, product, and financial markets, which are kept in the current model as well. While nominal and real rigidities constitute the core of a New Keynesian DSGE model, the choice of financial frictions warrants a brief discussion along the lines of Gerali et al. (2010). Both deposit and 
lending branches possess certain market power over savers and borrowers, which gives rise to a markdown and a markup of retail interest rates in the model. The spreads on interest rates in China are comparatively high, suggesting an environment of limited competition, informational frictions, and difficult substitutability between products and competitors. By the same token, we also keep the adjustment costs on retail interest rates and capital adequacy. They may represent in a tractable way operational and regulatory costs, asymmetric information, and risks. Having intertemporally optimizing banks enables window guidance to affect bank lending on the entire transition path and not only on the binding dates. We let the magnitude of these frictions be determined by the Chinese financialsector data. Because our central topic - window guidance practicesconcerns bank lending to the corporate sector, unlike Gerali et al. (2010), we abstract from lending to households and from housing markets.

\subsection{Households}

Time is discrete and indexed by $t$. Households, indexed by $j$, maximize their lifetime utility, discounted by $\beta_{P}^{t}$ subject to a usual budget constraint in real terms and a downward-sloping labor demand curve.

Their instantaneous utility depends positively on the difference between current consumption $c_{t}^{P}(j)$ and a fraction of aggregate lagged consumption $c_{t-1}^{P}$ (due to habit formation) and negatively on hours worked $l_{t}(j)$. Individual consumption preferences are subject to an exogenous disturbance $\epsilon_{t}^{z}$ that follows an $\mathrm{AR}(1)$ process. Households supply differentiated labor input and receive in return wages that are sticky in nominal terms. Their income is formed from payroll $w_{t} l_{t}(j)$, dividends $t_{t}^{P}(j)$, and real gross interest income on last period's deposits $\frac{\left(1+r_{t-1}^{d}\right) d_{t-1}(j)}{\pi_{t}}$. Current income is reduced by the quadratic wage adjustment costs $\Omega\left(W_{t}(j), W_{t-1}(j)\right)=$ $\frac{\kappa_{w}}{2}\left(\frac{W_{t}(j)}{W_{t-1}(j)}-\pi_{t-1}^{i_{w}}\right)^{2} \frac{W_{t}(j)}{P_{t}}$, where $W_{t}$ are nominal wages and $\pi_{t-1}^{i_{w}}$ is the wage indexation rule. Households use this income to buy consumption goods or save in new deposits $d_{t}(j)$. Inflation is denoted by $\pi_{t}$ and nominal wage inflation is defined as $\pi_{t}^{w}=\frac{w_{t}}{w_{t-1}} \pi_{t}$. 


$$
\begin{gathered}
\max _{c_{t}^{P}(j), d_{t}(j), l_{t}(j)} E_{0} \sum_{t=0}^{\infty} \beta_{P}^{t} \\
\times\left[\left(\frac{1-a^{P}}{1-\xi^{P}}\right) \epsilon_{t}^{z}\left(c_{t}^{P}(j)-a^{P} c_{t-1}^{P}\right)^{1-\xi^{P}}-\frac{l_{t}(j)^{1+\phi}}{1+\phi}\right] \\
c_{t}^{P}(j)+d_{t}(j) \leq w_{t} l_{t}(j)+\frac{\left(1+r_{t-1}^{d}\right) d_{t-1}(j)}{\pi_{t}} \\
\quad-\Omega\left(W_{t}(j), W_{t-1}(j)\right)+t_{t}^{P}(j) \\
l_{t}(j)=\left(\frac{W_{t}(j)}{W_{t}}\right)^{-\epsilon_{l}} l_{t},
\end{gathered}
$$

where $W_{t}$ and $l_{t}$ are aggregate wage and hours worked, respectively. The first-order conditions (FOCs) with regard to $c_{t}^{P}(j), d_{t}(j), l_{t}(j)$ are

$$
\begin{aligned}
\left(1-a^{P}\right) \epsilon_{t}^{z} & =\lambda_{t}^{P}\left(c_{t}^{P}(j)-a^{P} c_{t-1}^{P}\right)^{\xi^{P}} \\
\lambda_{t}^{P} & =\beta_{P} \lambda_{t+1}^{P}\left(\frac{1+r_{t}^{d}}{\pi_{t+1}}\right) \\
\kappa_{w}\left(\pi_{t}^{w}-\pi_{t-1}^{i_{w}} \bar{\pi}^{1-i_{w}}\right) \pi_{t}^{w}= & \beta E_{t}\left[\frac{\lambda_{t+1}^{P}}{\lambda_{t}^{P}} \kappa_{w}\left(\pi_{t+1}^{w}-\pi_{t}^{i_{w}} \bar{\pi}^{1-i_{w}}\right) \frac{\left(\pi_{t+1}^{w}\right)^{2}}{\pi_{t+1}}\right] \\
& +\left(1-\epsilon_{l}\right) l_{t}(j)+\epsilon_{l} \frac{l_{t}(j)^{1+\Phi}}{\lambda_{t}^{P} w_{t}} .
\end{aligned}
$$

Equations (1) and (2) form the Euler equation, while (3) is a wage Phillips curve.

\subsection{Entrepreneurs}

Entrepreneurs, indexed by $i$, combine capital $k_{t}^{E}(i)$ that depreciates at rate $\delta$, and labor $l_{t}(i)$, to produce a homogenous intermediate good in accordance with the standard Cobb-Douglas production function 9 The production function is subject to an

\footnotetext{
${ }^{9}$ The budget constraint of entrepreneurs expressed in terms of consumption goods and output is sold at producer prices. Thus, firm revenues should be discounted by a retail markup, $x_{t}$.
} 
autoregressive total factor productivity (TFP) shock, $A_{t}^{e}$. The real price of capital is denoted by $q_{t}^{k}$. Capital utilization rate, $u_{t}(i)$, can also vary over time and is chosen every period by entrepreneurs. Capital utilization costs are determined by the quadratic function $\psi\left(u_{t}(i)\right)$. The firms borrow $b_{t}(i)$ at nominal interest rate $r_{t}^{b E}$, to partially finance the purchase of productive capital and decide their consumption profile $c_{t}^{E}(i)$ to maximize lifetime utility from consumption, discounted by $\beta_{E}^{t}$. Borrowing is constrained by the total stock of capital.

$$
\begin{gathered}
\max _{c_{t}^{E}(i), b_{t}^{E}(i), k_{t}^{E}(i), u_{t}(i), l_{t}(i)} E_{0} \sum_{t=0}^{\infty} \beta_{E}^{t}\left[\left(\frac{1-a^{E}}{1-\xi^{E}}\right)\left(c_{t}^{E}(i)-a^{E} c_{t-1}^{E}\right)^{1-\xi^{E}}\right] \\
c_{t}^{E}(i)+w_{t} l_{t}(i)+\frac{\left(1+r_{t-1}^{b E}\right) b_{t-1}(i)}{\pi_{t}}+q_{t}^{k} k_{t}^{E}(i)+\psi\left(u_{t}(i)\right) k_{t-1}^{E}(i) \\
\leq \frac{y_{t}^{E}(i)}{x_{t}}+b_{t}(i)+q_{t}^{k}(1-\delta) k_{t-1}^{E}(i) \\
y_{t}^{E}(i)=A_{t}^{e}\left[u_{t}(i) k_{t-1}^{E}(i)\right]^{\alpha} l_{t}(i)^{1-\alpha} \\
\psi\left(u_{t}(i)\right)=\chi_{0}\left(u_{t}(i)-1\right)+\frac{\chi_{1}}{2}\left(u_{t}(i)-1\right)^{2} \\
\left(1+r_{t}^{b E}\right) b_{t}(i) \leq m_{t}^{E} E_{t}\left[q_{t+1}^{k}(1-\delta) k_{t}^{E}(i) \pi_{t+1}\right]
\end{gathered}
$$

The first-order conditions of the entrepreneurs' problem w.r.t. $c_{t}^{E}(i), k_{t}^{E}(i), l_{t}(i), b_{t}(i), u_{t}(i)$ are

$$
\begin{gathered}
\left(1-a^{E}\right)=\lambda_{t}^{E}\left(c_{t}^{E}(i)-a^{E} c_{t-1}^{E}\right)^{\xi^{E}} \\
\beta_{E} \lambda_{t+1}^{E}\left(q_{t+1}^{k}(1-\delta)+r^{k}(i)\right)-\psi\left(u_{t+1}(i)\right) \\
+\mu_{t}^{E}\left[m_{t}^{E} q_{t+1}^{k}(1-\delta) \pi_{t+1}\right]=\lambda_{t}^{E} q_{t}^{k} \\
r_{t}^{k}(i) k_{t}^{E}(i)=\alpha \frac{y_{t}^{E}(i)}{x_{t}} \\
w_{t} l_{t}=(1-\alpha) \nu \frac{y_{t}^{E}(i)}{x_{t}} \\
\lambda_{t}^{E}-\beta_{E} \lambda_{t+1}^{E}\left(\frac{1+r_{t}^{b E}}{\pi_{t+1}}\right)=\mu_{t}^{E}\left(1+r_{t}^{b E}\right) \\
r_{t}^{k}(i)=\chi_{0} u_{t}(i)+\chi_{1}\left(u_{t}(i)-1\right) .
\end{gathered}
$$




\subsection{Central Bank}

Inflation is the foremost goal of monetary policy in advanced economies. In China, the $\mathrm{PBoC}$ is mandated with maintaining overall stability. In other words, the $\mathrm{PBoC}$ may attach high priority to inflation fighting, but safeguarding high gross domestic product (GDP) growth rates is the top priority. In the modeling framework, the $\mathrm{PBoC}$ provides funds at the policy rate, $r_{t}$, and exchanges bonds denominated in foreign currency $\left(D_{t}^{*}\right)$ for assets in local currency $\left(D_{t}^{C B}\right) 10$

$$
\Delta D_{t}^{C B}=S_{t} \Delta D_{t}^{*}
$$

The Chinese capital account, as noted, is closed, so the usual UIP condition must be modified. The nominal exchange rate, $S_{t}$, reflects only partially the differences in interest rates at home and abroad, so

$$
\frac{S_{t+1}}{S_{t}}=\left(\frac{1+r_{t}}{1+r_{t}^{*}}\right)^{\kappa^{r}}, 0<\kappa^{r} \leq 1 .
$$

Monetary policy employs standard and nonstandard monetary tools. The standard monetary toolkit consists of a Taylor rule, whereby the PBoC sluggishly closes deviations of inflation from the long-run target rate and gaps between actual and potential output.

$$
\begin{aligned}
\left(1+r_{t}\right)= & (1+\bar{r})^{\left(1-\phi_{R}\right)}\left(1+r_{t-1}\right)^{\phi_{R}}\left(\frac{\pi_{t}}{\bar{\pi}}\right)^{\phi_{\pi}\left(1-\phi_{R}\right)} \\
& \times\left(\frac{y_{t}}{y_{t-1}}\right)^{\phi_{y}\left(1-\phi_{R}\right)} \epsilon_{t}^{r}
\end{aligned}
$$

When these coefficients are positive, monetary policy is said to be countercyclical. The coefficient $\phi_{R}$ captures the degree of inertia in monetary policy, implying that the $\mathrm{PBoC}$ adjusts the interest rate gradually toward its target rate.

In modeling window guidance, the descriptive empirical evidence in section 2 strongly argues for nonlinearity in the use of window guidance. In that spirit, we augment the PBoC's toolkit with a

\footnotetext{
${ }^{10}$ Exporters are obliged by law to exchange foreign assets with the central bank.
} 
nonlinear window guidance instrument. The attraction of integrating nonlinearities into DSGE models is that they can produce rich medium-term dynamics useful in shaping policy 11

The window guidance policy instrument in the PBoC's toolbox is modeled as follows. We first assume that the central bank has the power to define and implement a lower bound $B^{l b}$ and an upper bound $B^{u b}$ on the stock of loans to entrepreneurs. Irrespective of the means to achieve its goal (moral suasion or administrative measures), these limits are respected by the commercial banks. The rules for $B^{l b}$ and $B^{u b}$ are assumed to be symmetric, hence only the lower bound is described below for brevity:

$$
B^{l b}=\Delta^{l b} \bar{B}
$$

where $\bar{B}$ is the steady-state level of $B$. The fractions $\Delta^{l b}$ can be exogenously fixed by the monetary authority or can vary countercyclically with the business cycle stance, i.e., $\Delta^{l b}=\bar{\Delta}^{b}\left(\frac{Y}{\bar{Y}}\right)^{-\epsilon^{l b}}$, $\epsilon^{l b} \geq 0$. In other words, the window guidance reaction is a function of output alone. An important feature of the policy rule (16) is the assumed nonlinearity. We solve the model two ways: once assuming the loan constraint is slack (at first order) and once where the constraint is assumed to be occasionally binding.

Equation (16) can also be interpreted as an attempt to avoid the "dark corners" first noted by Blanchard (2014) 12 The nonstandard window guidance toolkit addresses situations in which the $\mathrm{PBoC}$ is limited in the use of its policy interest rate. Pointing out that standard Taylor rules lack this pronounced risk-avoidance property, Blanchard (2014) makes a strong case that macroeconomic policymakers should give high priority to avoiding dark corners and may have to resort to novel tools to do so.

\footnotetext{
${ }^{11}$ Nonlinear monetary policy reaction function has been studied largely in reduced-form empirical work, but not in a structural model. See, for example, Brüggemann and Riedel (2011), Cukierman and Muscatelli (2008), and Lamarche and Koustas (2012).

${ }^{12}$ Bernanke and Reinhart (2004) recommend aggressive preemptive measures to avoid the complications raised by the zero lower bound. In that light, equation (16) aims at providing insurance for avoiding severe recessions. In such "dark corners," the focus upon output appears to be an appropriate description of the behavior of Chinese policymakers.
} 
The next sections on commercial banks discuss how an occasionally binding window guidance constraint might affect bank behavior. Impulse response functions of the general equilibrium effect and the tradeoffs arising from the window guidance are explained in detail.

\subsection{Wholesale Banking}

The asset side of the wholesale bank sector comprises loans to firms $\left(B_{t}\right)$ and central bank bonds denominated in the domestic currency $\left(D_{t}^{C B}\right)$. On the liability side, wholesale banks combine deposits from households $\left(D_{t}\right)$ and bank capital $\left(K_{t}^{b}\right)$ :

$$
B_{t}+D_{t}^{C B}=D_{t}+K_{t}^{b} .
$$

Their real net worth evolves as a law of motion,

$$
\pi_{t} K_{t}^{b}=\left(1-\delta^{b}\right) K_{t-1}^{b}+j_{t-1}^{b},
$$

where $\delta^{b} K_{t-1}^{b}$ is the per-period cost for managing bank capital and $j_{t-1}^{b}$ is last period's real profits of financial intermediaries. To stabilize the capital adequacy ratio in the long run, it is necessary to introduce a (small) friction on the interbank market. The spread between loan rate $\left(R_{t}^{b}\right)$ and deposit rate $\left(R_{t}^{d}\right)$ should depend negatively on banks' leverage $\frac{K_{t}^{b}}{B_{t}}$. In the steady state, this margin disappears such that

$$
R_{t}^{b}-R_{t}^{d}=-\kappa_{K b}\left(\frac{K_{t}^{b}}{B_{t}}-\nu^{b}\right)\left(\frac{K_{t}^{b}}{B_{t}}\right)^{2} .
$$

Following Gerali et al. (2010), we assume that deposit rates on the wholesale market are equal to the policy rate $\left(r_{t}\right): R_{t}^{d}=r_{t}$.

\subsubsection{Retail Banking}

Financial flows are channeled through an imperfectly competitive banking sector. Banks supply deposits and loans to their agents, and set interest rates on both deposits and loans to maximize profits. Retail banks supply slightly differentiated credit services, $b_{t}^{E}(j)$, to firms. Facing quadratic adjustment costs and taking into account the downward-sloping demand for loans, they set up interest rates 
in a sticky manner. This gives rise to positive markup for interest rates on loans to firms $\left(r_{t}^{b}\right)$ over the interest rates prevailing on wholesale money market $\left(R_{t}^{b}\right)$. Sectoral profits are countercyclical in equilibrium. The objective of a retail lending bank is to maximize its profits, discounted by the consumption-based discount factor $\left(\Lambda_{0, t}^{P}\right)$ :

$$
\begin{aligned}
& \max _{r_{t}^{b}(j)} E_{0} \sum_{t=0}^{\infty} \Lambda_{0, t}^{P} \\
& \quad \times\left[r_{t}^{b}(j) b_{t}^{E}(j)-R_{t}^{b} b_{t}^{E}(j)-\frac{\kappa_{b E}}{2}\left(\frac{r_{t}^{b}(j)}{r_{t-1}^{b}(j)}-1\right)^{2} r_{t}^{b} b_{t}^{E}\right],
\end{aligned}
$$

where $b_{t}^{E}$ is the average level of retail bank loans. The downwardsloping demand for loans is expressed as

$$
b_{t}^{E}(j)=\left(\frac{\mathrm{r}_{t}^{b}(j)}{r_{t}^{b}}\right)^{-\epsilon^{b}} b_{t}^{E},
$$

where $\epsilon^{b}$ is the elasticity of loan demand. The existence of a lower bound on loans to firms enters the commercial banks' model block via a Lagrange multiplier $\lambda^{B}$. Assuming a symmetric equilibrium, the FOC w.r.t. $r_{t}^{b}$ is

$$
\begin{aligned}
1- & \epsilon^{b}+\epsilon^{b} \frac{R_{t}^{b}}{r_{t}^{b}}-\kappa_{b}\left(\frac{r_{t}^{b}}{r_{t-1}^{b}}-1\right) \frac{r_{t}^{b}}{r_{t-1}^{b}} \\
& +\Lambda_{t, t+1}^{P} \kappa_{b}\left(\frac{r_{t+1}^{b}}{r_{t}^{b}}-1\right)\left(\frac{r_{t+1}^{b}}{r_{t}^{b}}\right)^{2} \frac{b_{t+1}^{E}}{b_{t}^{E}}-\frac{\lambda^{B} \epsilon^{b}}{r_{t}^{b}}=0 .
\end{aligned}
$$

Following the Kuhn-Tucker necessary conditions for an optimum, one of two cases-(i) $\lambda^{B}=0 ; b_{t}^{E}>b^{l b}$ or (ii) $\lambda^{B}>0 ; b_{t}^{E}=b^{l b}$ must hold. The more binding the lower bound on credit, the greater the shadow price $\lambda^{B}$.

By (21), it follows that $r_{t}^{b}$ should decline. The economic intuition here is that interest rates must be lower than in the unconstrained case in order to accommodate the increase in credit supply. Since the model assumes full rationality and perfect foresight, banks on impact anticipate that the constraint ultimately binds. Given that lending rates are sticky, banks react to these expectations in advance 
by inducing a milder credit crunch than in the case without window guidance, and thus avoid spending time in a constrained regime that is more costly to them than an interior equilibrium.

\subsubsection{Deposit Branch}

The deposit branch supplies differentiated deposit services, $d_{t}^{P}(j)$, to patient households at interest rates, $r_{t}^{d}(j)$, that are lower than on the wholesale market due to their monopolistic power. Limited participation prevents households from transacting directly with the wholesale branch or with foreign lenders, or arbitraging away the markdown on retail deposit rates. The intertemporal optimization of a retail deposit bank is

$$
\max _{r_{t}^{d}(j)} E_{0} \sum_{t=0}^{\infty} \Lambda_{0, t}^{P}\left[r_{t} d_{t}^{P}(j)-r_{t}^{d}(j) d_{t}^{P}(j)-\frac{\kappa_{d}}{2}\left(\frac{r_{t}^{d}(j)}{r_{t-1}^{d}(j)}-1\right)^{2} r_{t}^{d} d_{t}\right],
$$

where $d_{t}$ is the average level of retail bank deposits. The upwardsloping demand for deposits is expressed as

$$
d_{t}^{P}(j)=\left(\frac{r_{t}^{d}(j)}{r_{t}^{d}}\right)^{\epsilon^{d}} d_{t}
$$

Assuming a symmetric equilibrium, the FOCs w.r.t. $r_{t}^{d}$ are

$$
\begin{aligned}
& -1+\epsilon^{d}-\epsilon^{d} \frac{r_{t}}{r_{t}^{d}}-\kappa_{d}\left(\frac{r_{t}^{d}}{r_{t-1}^{d}}-1\right) \frac{r_{t}^{d}}{r_{t-1}^{d}} \\
& +\Lambda_{t, t+1}^{P} \kappa_{d}\left(\frac{r_{t+1}^{d}}{r_{t}^{d}}-1\right)\left(\frac{r_{t+1}^{d}}{r_{t}^{d}}\right)^{2} \frac{d_{t+1}}{d_{t}}=0 .
\end{aligned}
$$

\subsection{Retailers in the Goods Market}

Retailers costlessly repackage homogenous domestic intermediate goods into differentiated final goods. They set up domestic prices subject to quadratic adjustment costs and a downward-sloping demand curve. A well-known New Keynesian Phillips curve for domestic inflation, $\pi_{t}^{H}$, emerges, i.e., 


$$
\begin{aligned}
1- & \epsilon^{y}+\frac{\epsilon^{y}}{\mathrm{x}_{t}}-\kappa_{p}\left[\pi_{t}^{H}-\left(\pi_{t-1}^{H}\right)^{\iota}\left(\bar{\pi}^{H}\right)^{1-\iota}\right] \pi_{t}^{H} \\
& +\Lambda_{t, t+1}^{P} \kappa_{p}\left[\pi_{t+1}^{H}-\left(\pi_{t}^{H}\right)^{\iota}\left(\bar{\pi}^{H}\right)^{1-\iota}\right]\left(\pi_{t+1}^{H}\right)^{2} \frac{Y_{t+1}}{Y_{t}}=0 .
\end{aligned}
$$

The optimal bundle of domestic products, $C_{t}^{H}$, is combined with imported goods, $C_{t}^{F}$, with the objective to minimize costs. Denote the domestic price level relative to aggregate consumer prices as $p_{t}^{H}=P_{t}^{H} / P_{t}$ and the relative price of imported goods as $p_{t}^{F}=P_{t}^{F} / P_{t}$. Then

$$
\begin{aligned}
C_{t}= & {\left[\left(\eta^{c}\right)^{1 / \epsilon^{c}}\left(C_{t}^{H}\right)^{\left(\epsilon^{C}-1\right) / \epsilon^{C}}\right.} \\
& \left.+\left(1-\eta^{c}\right)^{1 / \epsilon^{c}}\left(C_{t}^{F}\right)^{\left(\epsilon^{C}-1\right) / \epsilon^{C}}\right]^{\epsilon^{C} /\left(\epsilon^{C}-1\right)},
\end{aligned}
$$

and

$$
1=\eta^{c}\left(p_{t}^{H}\right)^{1-\epsilon^{C}}+\left(1-\eta^{c}\right)\left(p_{t}^{F}\right)^{1-\epsilon^{C}} .
$$

Optimization sets up the ratio of the two consumption bundles as a function of the relative prices (real effective exchange rate):

$$
\frac{C_{t}^{H}}{C_{t}^{F}}=\frac{\eta^{c}}{1-\eta^{c}}\left(\frac{P_{t}^{H}}{P_{t}^{F}}\right)^{-\epsilon^{C}} .
$$

By analogy, aggregate investment prices and quantities, as well as the ratio of domestic to foreign investment goods are given by

$$
\begin{gathered}
1=\eta^{I}\left(p_{t}^{I, H}\right)^{1-\epsilon^{I}}+\left(1-\eta^{I}\right)\left(p_{t}^{I, F}\right)^{1-\epsilon^{I}} \\
I_{t}=\left[\left(\eta^{I}\right)^{1 / \epsilon^{I}}\left(I_{t}^{H}\right)^{\left(\epsilon^{I}-1\right) / \epsilon^{I}}+\left(1-\eta^{I}\right)^{1 / \epsilon^{I}}\left(I_{t}^{F}\right)^{\left(\epsilon^{I}-1\right) / \epsilon^{I}}\right]^{\epsilon^{I} /\left(\epsilon^{I}-1\right)} \\
\frac{I_{t}^{H}}{I_{t}^{F}}=\frac{\eta^{I}}{1-\eta^{I}}\left(\frac{P_{t}^{H}}{P_{t}^{F}}\right)^{-\epsilon^{I}}
\end{gathered}
$$




\subsection{Net Exports}

The volume of exports depends on the relative prices of domestic and foreign goods.

$$
\frac{C_{t}^{H *}}{C_{t}^{*}}=\left(\frac{P_{t}^{H *}}{P_{t}^{*}}\right)^{-\epsilon^{F}}
$$

The real effective exchange rate in the end determines the trade balance of the country by altering foreign demand for exports and domestic demand for imports.

\subsection{Capital Producers}

In the capital-goods-producing sector, producers buy old capital and convert it to new productive capital according to the law of motion $K_{t}=(1-\delta) K_{t-1}+\left(1-\frac{\kappa_{i}}{2}\left(\frac{I_{t}}{I_{t-1}}-1\right)^{2}\right) I_{t}$. As in Gerali et al. (2010), producers of physical capital goods are used as a modeling device to make explicit the dependence of price of capital on lagged, contemporaneous, and future investment levels, $\left(I_{t-1}, I_{t}, I_{t+1}\right)$, or Tobin's Q, which enters the borrowing constraint of entrepreneurs. During the upturn, rising capital prices relax the borrowing constraint of entrepreneurs, thus amplifying and propagating the initial shock. The FOC is as follows:

$$
\begin{aligned}
1= & q_{t}^{K}\left(1-\frac{\kappa_{i}}{2}\left(\frac{I_{t}}{I_{t-1}}-1\right)^{2}-\kappa_{i}\left(\frac{I_{t}}{I_{t-1}}-1\right) \frac{I_{t}}{I_{t-1}}\right) \\
& +\Lambda_{t, t+1}^{E} q_{t+1}^{K} \kappa_{i}\left(\frac{I_{t+1}}{I_{t}}-1\right)\left(\frac{I_{t+1}}{I_{t}}\right)^{2} .
\end{aligned}
$$

\subsection{Market Clearing}

Budget constraints must be satisfied. Thus, wages should clear the labor market and the real effective exchange rates should achieve domestic market equilibrium. The two equations that close the system are $y_{t}^{E}=C_{t}^{H}+q_{t}^{k} I_{t}^{H}+C_{t}^{H *}$ and $C_{t}=c_{t}^{P}+c_{t}^{E}$. 


\section{Model Calibration, Impulse Response Functions, and Welfare Analysis}

We next describe how we have chosen parameters for our model. The model is parameterized to match key features of the Chinese economy. Specifically, we partition the model parameters into two sets. The first set of parameters can be recovered from targeting great ratios and other first moments of data. The parameters in the second group, describing adjustment costs, are uncovered from second moments of the observed series. We also fix certain parameters to conventional values. Data from our primary source, the National Bureau of Statistics of China, are augmented with up-to-date series from the IMF (2017a, p. 46), the World Bank database, and PBoC annual reports. Although the model is quarterly, annual figures are targeted due to limited quarterly data availability. Model calibration is broadly in line with the estimates of deep parameters presented in Dai, Minford, and Zhou (2015), Le et al. (2014), and Li and Liu (2017).

\subsection{Calibrated Parameters}

The risk-aversion/intertemporal substitution parameters are calibrated to a conventional value $-\xi^{P}, \xi^{E}=213$ See table 3. Demand elasticity for differentiated labor input is calibrated to higher values than in Gerali et al. (2010), so that lower wage markup is achieved, $\frac{\epsilon_{l}}{\left(\epsilon_{l}-1\right)}=1.2$. We choose the inverse Frisch elasticity of labor supply to be $\phi=1$, the same as in Gerali et al. (2010) 14 The elasticity of foreign interest rates $\left(r^{*}\right)$ to the ratio of foreign assets to GDP is held to 0.1 percent, so as not to affect short-term dynamics but still ensure that foreign debt does not follow a random walk. The exchange rate elasticity to the spread between domestic and foreign interest rates, i.e., the openness of China's current and capital account, is kept low

\footnotetext{
${ }^{13}$ As noted by Thimme (2017), it is notoriously difficult to obtain reliable empirical estimates of the parameter of intertemporal substitution in consumption. Hence, we do not use it to match actual data.

${ }^{14}$ Macro and micro estimates of Frisch elasticity differ, with micro studies typically finding values below one, while values used in macro models are usually greater than one.
} 
Table 3. Calibrated Parameters

\begin{tabular}{|c|c|c|}
\hline Parameter & Description & Value \\
\hline$\beta_{P}$ & Discount Factor of Households & 0.997 \\
\hline$\beta_{E}$ & Discount Factor of Entrepreneurs & 0.983 \\
\hline$\epsilon^{d}$ & Demand Elasticity for Deposits & 1.31 \\
\hline$\kappa_{d}$ & Deposit Rate Adjustment Cost & 1.49 \\
\hline$\epsilon^{b s}$ & Demand Elasticity for Loans & 2.37 \\
\hline$\kappa_{b E}$ & Lending Rate Adjustment Cost & 15.9 \\
\hline$\delta^{b}$ & Commercial Banks Capital Depreciation Rate & 0.08 \\
\hline$\nu^{b}$ & Target Capital Adequacy Ratio & 0.1 \\
\hline$\kappa_{K b}$ & $\begin{array}{l}\text { Elasticity of the Spread on the Interbank Market } \\
\text { w.r.t. Banks' Leverage }\end{array}$ & 16.9 \\
\hline$\kappa^{\tau}$ & $\begin{array}{l}\text { Exchange Rate Elasticity to the Spread between } \\
\text { Domestic and Foreign Interest Rates }\end{array}$ & 0.001 \\
\hline$a^{P}$ & Habit Formation Parameter & 0.86 \\
\hline$\xi^{P}$ & $\begin{array}{l}\text { Inverse of the Elasticity of Intertemporal } \\
\text { Substitution for Households }\end{array}$ & 2 \\
\hline$\xi^{E}$ & $\begin{array}{l}\text { Inverse of the Elasticity of Intertemporal } \\
\text { Substitution for Entrepreneurs }\end{array}$ & 2 \\
\hline$\epsilon_{l}$ & Demand Elasticity for Differentiated Labor Input & 6.3 \\
\hline$\kappa_{w}$ & Wage Adjustment Cost & 85.5 \\
\hline$i_{w}$ & Wage Indexation Parameter & 0.83 \\
\hline$m^{E}$ & Loan-to-Value Constraint Parameter & 0.48 \\
\hline$\alpha$ & Output Elasticity of Capital & 0.5 \\
\hline$\delta$ & Depreciation Rate & 0.03 \\
\hline$\kappa_{i}$ & Capital Adjustment Cost Parameter & 2.4 \\
\hline$\phi$ & Inverse Frisch Elasticity of Labor Supply & 1 \\
\hline$\epsilon^{y}$ & Demand Elasticity for Differentiated Goods & 21 \\
\hline$\kappa_{p}$ & Price Adjustment Cost & 39.7 \\
\hline$\iota$ & Price Indexation Parameter & 0.41 \\
\hline$\epsilon^{C}$ & Demand Elasticity for Domestic Consumer Goods & 5 \\
\hline$\epsilon^{I}$ & Demand Elasticity for Domestic Investment Goods & 5 \\
\hline$\epsilon^{F}$ & Foreign Demand for Domestic Goods (Exports) & 5 \\
\hline$\eta^{c}$ & Home Bias Parameter for Consumption Goods & 0.77 \\
\hline$\eta^{I}$ & Home Bias Parameter for Investment Goods & 0.77 \\
\hline$\chi_{0}$ & Capital Utilization Adjustment Cost (Linear Part) & 0.042 \\
\hline$\chi_{1}$ & $\begin{array}{l}\text { Capital Utilization Adjustment Cost (Nonlinear } \\
\text { Part) }\end{array}$ & 0.0042 \\
\hline$\phi_{R}$ & Policy Inertia Parameter in the Taylor Rule & 0.82 \\
\hline$\phi_{\pi}$ & Inflation Parameter in the Taylor Rule & 1.76 \\
\hline$\phi_{y}$ & Output Parameter in the Taylor Rule & 0.83 \\
\hline$\sigma_{C}$ & Standard Deviation of Consumption Shock & 0.0732 \\
\hline$\sigma_{I}$ & Standard Deviation of Investment Shock & 0.0147 \\
\hline$\sigma_{m k}$ & $\begin{array}{l}\text { Standard Deviation of Financial Intermediation } \\
\text { Shock }\end{array}$ & 0.0688 \\
\hline$\rho_{C}$ & AR(1) Coefficient of Consumption Shock & 0.0876 \\
\hline$\rho_{I}$ & AR(1) Coefficient of Investment Shock & 0.0001 \\
\hline$\rho_{m k}$ & $\begin{array}{l}\text { AR(1) Coefficient of Financial Intermediation } \\
\text { Shock }\end{array}$ & 0.0001 \\
\hline
\end{tabular}


Table 4. Steady-State Values of Endogenous Variables

\begin{tabular}{|l|l|c|}
\hline Parameter & \multicolumn{1}{|c|}{ Description } & Value \\
\hline$r^{d}$ & Real Interest Rates on Retail Deposits (Annual) & $1.3 \%$ \\
$r^{b E}$ & Real Interest Rates on Retail Loans (Annual) & $4 \%$ \\
$r$ & Policy Interest Rate & $2.3 \%$ \\
$1+x$ & Price Markup & 1.05 \\
$x \frac{r k}{y}$ & Capital Income Share & 0.5 \\
$k / y$ & Capital-to-GDP Ratio (Annualized Ratio) & 2.8 \\
$C / Y$ & Consumption Share in GDP & 0.65 \\
$I / Y$ & Investment Share in GDP & 0.32 \\
$\frac{C^{F}+I^{F}}{Y}$ & Import Share in GDP & 0.22 \\
$C^{H^{*}}$ & Export Share in GDP & 0.25 \\
$\frac{B}{Y}$ & Loans to Nonfinancial Corporations to GDP & 1.3 \\
$\frac{D^{C B}}{Y}$ & (Annualized Ratio) & 0.5 \\
& Central Bank's Bonds in Domestic Currency, Held & \\
$\frac{B}{K}$ & by Commercial Banks, to GDP (Annualized & \\
$\frac{K^{b}}{B}$ & Ratio) & 0.66 \\
\hline
\end{tabular}

at $\kappa^{r}=0.001$, reflecting the very gradual pass-through of interest rate differentials to nominal exchange rate movements.

\subsection{Matching the Steady State}

The household annual discount rate, calibrated to a conventional level of 1.3 percent, implies a quarterly discount factor $\beta_{\mathrm{P}}=0.99715$ The annual discount rate for entrepreneurs is set to 7 percent, implying the quarterly discount factor $\beta_{E}=0.983$. The steady-state real annual interest rate on loans $\left(r^{b E}\right)$ is calibrated to 4 percent, i.e., the average PPI-deflated rate on one-year loans over the period 2010-15. The entrepreneur's discount factor and lending rates jointly determine the steady-state rate of return on capital. See table 4.

The model assumes that in the steady state the official policy rate $\left(r_{t}\right)$ is transmitted to the interbank market $\left(R^{b}\right)$ via arbitrage, where it serves as a basis for pricing deposit and loan rates. The average

\footnotetext{
${ }^{15}$ The financial repression of China's financial system makes it impossible to recover the discount rate from historical data.
} 
one-year SHIBOR (Shanghai interbank offered rate) for the period 2010-15 is 4.2 percent. The seven-day repo rate average during 201115 is 4.8 percent. The real interbank interest rate is calculated by deflating the nominal one with 2 percent steady-state inflation, i.e., the average annual CPI inflation for the past 20 years in China. The spreads of deposit and lending rates with respect to the interbank market determine the parameters of market power by branches of retail banks $\left(\epsilon^{d}, \epsilon^{b s}\right)$.

The national accounts reflect China's sky-high investment-toGDP ratio, which averaged 45 percent in the period 2010-16. The aggregate figures conceal an important distinction between different components of total investment. Infrastructure projects constitute a sizable share of fixed-asset investment, averaging 22 percent between 2010 and 2016 16 We exclude this type of capital formation, when we construct the calibration target for the share of investment to GDP, for two reasons. First, in the model, investment decisions are made optimally by private agents, while decisions on acceleration/deceleration of infrastructure projects are centralized and with the aim to support the economy. Second, infrastructure capital stock would not enter the production function in the same way as private capital, nor are they necessarily a market product per se. The share of non-infrastructure investment in GDP that we target is 32 percent, which corresponds to the average for the period 200316. Given the high investment rate, depreciation is calibrated at a quarterly rate of $\delta=0.03$. In a balanced growth context, a high depreciation rate is necessary to cover both the attrition of existing capital and labor-augmenting technological progress. The parameters $\chi_{0}, \chi_{1}$ describe the costs of changing capital utilization rates. In order to ensure that capital operates at full capacity at steady state, we equate the linear term with the return on capital $\chi_{0}=r^{k}=0.042$. The quadratic cost parameter is set to $\chi_{1}=0.1 \chi_{0}$. Both values are close to those reported in Gerali et al. (2010).

Output elasticity of capital $\alpha$ targets the capital income share stated in the income account. Published figures show that gross operating surplus formed 50 percent and 55 percent of aggregated gross product in 2012-14. Zhang (2016) cites higher values for labor

\footnotetext{
${ }^{16}$ Please refer to online appendix $\mathrm{H}$, for an empirical presentation of the various components of total investment expenditures.
} 
income as a percentage of GDP, i.e., an average of 60 percent for the period 2010-15. In the model, capital income share is calibrated to $\alpha=0.5$. Bank loans to entrepreneurs $(B)$ are set at 130 percent of annual GDP in the model. The empirical counterpart of this variable would be the item "Bank Credit to Private Non-financial Sector" in the Bank for International Settlements (BIS) data tables. Central banks' bonds in domestic currency $\left(D^{C B}\right)$, held by the banking sector, are 50 percent of annual GDP in the model, reflecting the data in the "Balance Sheet of Other Depository Corporations."

These calibration targets give rise to high leverage $(B / K=0.46)$ in the nonfinancial corporate sector. The capital adequacy ratio of banks is governed by the parameter $\nu^{b}=0.1$, thus matching the average tier 1 capital adequacy ratio of the Chinese banking sector for 2013-15 as reported by the IMF (2017a, p. 46). Commercial banks' capital depreciation rate should stabilize bank capital given the steady-state profits, which implies $\delta^{b}=0.08$.

Net exports are calibrated at 3 percent of GDP, matching the average since 2009. Demand elasticity in the Dixit-Stiglitz aggregator $\left(\epsilon^{y}\right)$ is calibrated to achieve a markup of 5 percent for final goods prices from intermediate goods prices. The home-bias parameters $\left(\eta^{c}, \eta^{I}\right)$ are adjusted to replicate the average share of exports and imports in GDP in the period 2009-15.

\subsection{Matching Second Moments}

Adjustment costs and habit formation disappear from the deterministic steady state and can be uncovered by targeting second moments of detrended data. The same holds true for the parameters that describe central banks' reaction function and for demand elasticities when steady-state relative prices are calibrated at unity. Furthermore, the type, magnitude, and persistence of the shocks that drive the economic cycle crucially determine the link between parameters and data statistics, as well as the overall fit of the model. Chinese macroeconomic series exhibit less persistence after detrending, as well as lower contemporaneous correlation between GDP and domestic absorption components (consumption and investment). These stylized facts suggest that adjustment costs are likely to be smaller than in a typical calibration of a developed economy, in line with the findings in Dai, Minford, and Zhou (2015) and Le et al. (2014). 
Next, we discuss how different parameters affect second moments of selected macroeconomic time series. Then we describe the method we employ to estimate the parameters in question and the results obtained.

\subsubsection{Estimation Procedure}

The remaining parameters of interest are estimated by the method of moments using observables from the real economy (output, private consumption, investment, price inflation, and real wage dynamics) and four financial measures - the capital adequacy ratio, the three-month SHIBOR interest rate, plus the official interest rates on loans and deposits. The variables are observed at annual frequency in the periods $2000-06$ and $2010-1617$ The pre- and postcrisis years 2007-09 are excluded from the sample, since the series exhibit exceptionally high volatility and very little persistence in this period, partly reflecting high public investment spending and other strong administrative measures and interventions. First of all, the targeted moments include the standard deviations of all variables, except the official interest rates on loans and deposits, and the first-order autocorrelations of the real economy variables, plus the SHIBOR. Further targeted moments are the contemporaneous cross-correlations of GDP with all real economy variables and the SHIBOR, price inflation with wage inflation and the SHIBOR, and SHIBOR and the official interest rates on loans and deposits.

Output, private consumption, and investment are deflated with the appropriate price index, and then HP filtered $(\lambda=$ $6.25)$. This data set provides 22 moments - seven standard deviations, nine cross-correlations, and six autocorrelations. On the other side we have 19 parameters of interest-three Taylor coefficients $\left(\phi_{\pi}, \phi_{y}, \phi_{R}\right)$, five nominal/real rigidities parameters $\left(\kappa_{p}, \kappa_{w}, \kappa_{i}, \iota, i_{w}\right)$, two consumption preferences $\left(\epsilon^{C}, a^{P, E}\right)$, three financial frictions $\left(\kappa_{K b}, \kappa_{b E}, \kappa_{d}\right)$-and we specify three shocksa consumption shock, an investment shock, and a financial

\footnotetext{
${ }^{17}$ The quarterly model is appended by auxiliary variables that correspond to the annual figures in data.
} 
intermediation shock - that give rise to an additional six shock parameters $\left(\sigma_{C}, \sigma_{I}, \sigma_{m k}, \rho_{C}, \rho_{I}, \rho_{m k}\right) 18$

Ideally, each parameter should affect only a subset of the 22 moments of data. The habit persistence parameter $\left(a^{P}\right)$ affects primarily the cross-correlations between consumption and the other time series. The demand elasticity for imports/exports $\left(\epsilon^{C, I, F}\right)$ has a large effect on the cross-correlations between inflation and the rest of the variables, while it barely changes the cross-correlations with the real wage inflation and the $\operatorname{AR}(1)$ coefficients. The adjustment costs for real wages $\left(\kappa_{w}\right)$ have a large impact on the autocorrelations of order one as well as the cross-correlations of inflation and of real wage growth. Price adjustment costs $\left(\kappa_{p}\right)$ affect mostly the cross-correlations of price inflation and of real wage inflation. The two indexation coefficients, for prices $(\iota)$ and wages $\left(i_{w}\right)$, are relatively weakly identified by the data set. The quadratic adjustment costs for changing interest rates on loans $\left(\kappa_{b E}, \kappa_{d}\right)$ affect the correlation of the interbank rate vis-à-vis the official lending and deposit rates, while the leverage adjustment cost $\left(\kappa_{K b}\right)$ affects the dynamics of capital adequacy ratio. The Taylor coefficients $\left(\phi_{\pi}, \phi_{y}, \phi_{R}\right)$, the capital adjustment parameter $\left(\kappa_{i}\right)$, and the shock parameters $\left(\sigma_{C}, \sigma_{I}, \sigma_{m k}, \rho_{C}, \rho_{I}, \rho_{m k}\right)$, however, have sizable impact on all statistics simultaneously. It is impossible to isolate the effect of each of these parameters on the objective function and solve the system by blocks. Hence, we resort to the MATLAB's constrained nonlinear solver fmincon. This procedure finds a minimum of the objective function, given a set of constraints and an initial value for the parameters of interest. There is no guarantee that the minimum found is a global minimum. In fact, the estimates of price/wage adjustment costs $\left(\kappa_{p}, \kappa_{w}\right)$, for capital adjustment costs $\left(\kappa_{i}\right)$ and for financial frictions $\left(\kappa_{K b}, \kappa_{b E}, \kappa_{d}\right)$ vary widely with the initial values, suggesting multiple local equilibriums 19 We tackle this issue by sampling

\footnotetext{
${ }^{18}$ The estimation could potentially include a host of various shocks that may account for the cyclical movements of Chinese economy. Our choice of picking these three shocks aims at parsimony, while achieving relatively good data fit. Dai, Minford, and Zhou (2015) also find that consumption and investment shocks account for most of the variance in the observable series.

${ }^{19}$ The estimates of other parameters also depend on initial values, although to a lesser extent. These include parameters $\phi_{y}, a^{P}, i_{w}, \iota$. The nonconvexity of the objective function arises because of the nonlinear link between deep parameters
} 


\section{Figure 3. Model Fit with Respect to the Chosen Data Moments}

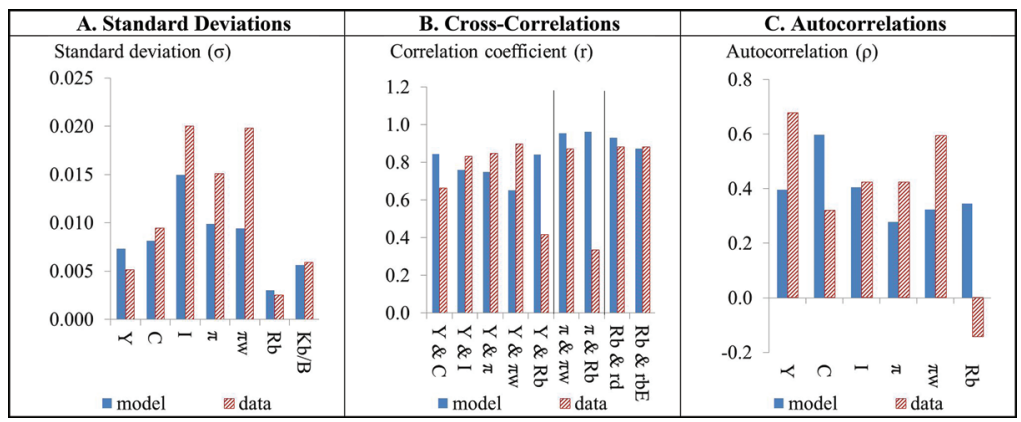

Notes: $Y$ is GDP, $C$ is consumption, $I$ is investment, $\pi$ is inflation, $\pi^{w}$ is real wage inflation, $R^{b}$ is SHIBOR, $r^{d}$ is interest rate on deposits, $r^{b E}$ is interest rate on loans, and $K^{b} / B$ is capital adequacy ratio. In panel $\mathrm{B}$, there are three sets of cross-correlations: (i) cross-correlations of GDP $(Y)$ with other variables, (ii) cross-correlations of inflation $(\pi)$ with real wage inflation $\left(\pi^{w}\right)$ and SHIBOR $\left(R^{b}\right)$, and (iii) cross-correlations of SHIBOR $\left(R^{b}\right)$ with official interest rates $\left(r^{d}\right)$ on deposits and loans $\left(r^{b E}\right)$.

1,000 initial parameter values from the parameter set and finding the local minimum for each of the initial values. Subsequently, we select the estimates that produce the smallest distance between data and model.

Figure 3 compares the model-implied moments and those in the data. Given the complexity of the modeling framework, the model matches relatively well the cross-correlations between output and real variables, between inflation and wage growth, and among interest rates. It shows higher cross-correlation of interbank rates with output and with inflation, while it falls short in replicating standard deviations of investment, inflation, and wage growth. There are some mild sign differences as well. In the data, consumption is less correlated with output than investment is, but in the model this

and moments and the possible tradeoffs in matching some dimensions of the data, i.e., high values of the parameter favor a subset of the matched moments, while low values match another subset of moments better. Structural breaks could also contribute to the existence of multiple local minimums, as deep parameters may not be stable. Weak identification may explain the changing estimates of $i_{w}$ and $\iota$ w.r.t. initial values. 
is reversed. Model-implied autocorrelation of investment is matched well. Output, inflation, and wage dynamics exhibit higher persistence in data than in the model, while consumption is more persistent in the model. Overall, one can say that the calibrated model is able to replicate the cyclical patterns of the Chinese data.

\subsubsection{Parameterization}

The Taylor coefficients show considerable interest rate smoothing and a moderate reaction to inflation and to output. The price elasticity of imports and exports is high, suggesting high substitutability of internationally traded goods. Dai, Minford, and Zhou (2015) and Le et al. (2014) argue that substitutability of import/export goods cannot be uncovered from data, since decisions on quantities of imports and exports are made on a centralized level. Despite the fact that price elasticities may not reflect "deep" preference parameters, they provide an important adjustment channel, so we keep the estimated parameters. In accordance with the data as well as Dai, Minford, and Zhou (2015) and Le et al. (2014), capital adjustment costs are relatively low. The estimates reveal moderate wage and price stickiness. Prices are comparatively flexible, while wages are more inelastic and indexed by past dynamics. These findings are in line with those of Dai, Minford, and Zhou (2015) and Le et al. (2014), where wage indexation is stronger than price indexation. The estimate reveals rigidities on both retail lending $\left(\kappa_{b E}\right)$ and wholesale market $\left(\kappa_{K b}\right)$, while deposit rates are flexible. The estimated shock parameters show sizable roles for consumption and investment disturbances and small persistence for all three shocks.

\subsection{Impulse Response Functions}

As a first model evaluation, we model two shocks: a positive consumption shock and a negative investment shock. The size of the shocks is chosen so that the limit on loans binds for several periods. For lower magnitude shocks, the constraint does not bind, so impulse responses of our no-window-guidance and with-windowguidance cases coincide 20

\footnotetext{
${ }^{20}$ Because the model is linearized, certainty equivalence holds. In higher-order approximations, impulse responses will differ even for shocks that fail to reach
} 
The model is solved up to first-order approximation with the help of the Dynare MATLAB toolbox (see Adjemian et al. 2014). The computation of impulse responses with occasionally binding constraints is implemented with the OccBin toolkit (see Guerrieri and Iacoviello 2015). The toolbox initially guesses the periods when the constraint is binding, then computes the optimal piecewise transition paths and verifies/rejects its guess. If the guess is incorrect, it guesses again until convergence is validated. As explained in section 3, lending rates have to fall relative to the no-window-guidance scenario to keep credit above the equilibrium transition path. Favorable financing conditions for firms stoke recovery through improved investment and income, but it remains an open question as to how much financial fragility is generated through impaired bank profits, especially if the poor financial performance of banks drags on.

For reasons of space, the impulse responses are presented in online appendix I. In each graph, the results are presented with or without the additional window guidance policy tool. The presentation in the appendix also contains a detailed explanation of the numerical results. A provisional conclusion from the impulse response analysis is that window guidance may help deliver additional monetary stimulus in challenging macroeconomic environments.

\subsection{Window Guidance in the Great Recession}

Structural models, DSGE models in particular, are suitable for discussing important economic events, as they explicitly account for various external shocks and macroeconomic channels, potentially relevant for the period in question. In the context of the current paper's topic, the macroeconomic effect of window guidance practices of the $\mathrm{PBoC}$ is probably best assessed in the period of the global financial crisis 2008-09, when the lower bound on credit activity had been binding most.

In China the output gap turned deeply negative in the fourth quarter of 2008 and closed by the end of 2010. The same period also

the lower bound on loans. A precautionary motive emerges: banks may want to step up lending activity to stay away from the contingency of hitting the floor on lending. 


\section{Figure 4. IRFs from a Financial Intermediation Shock without (- $)$ and with (-) Window Guidance}
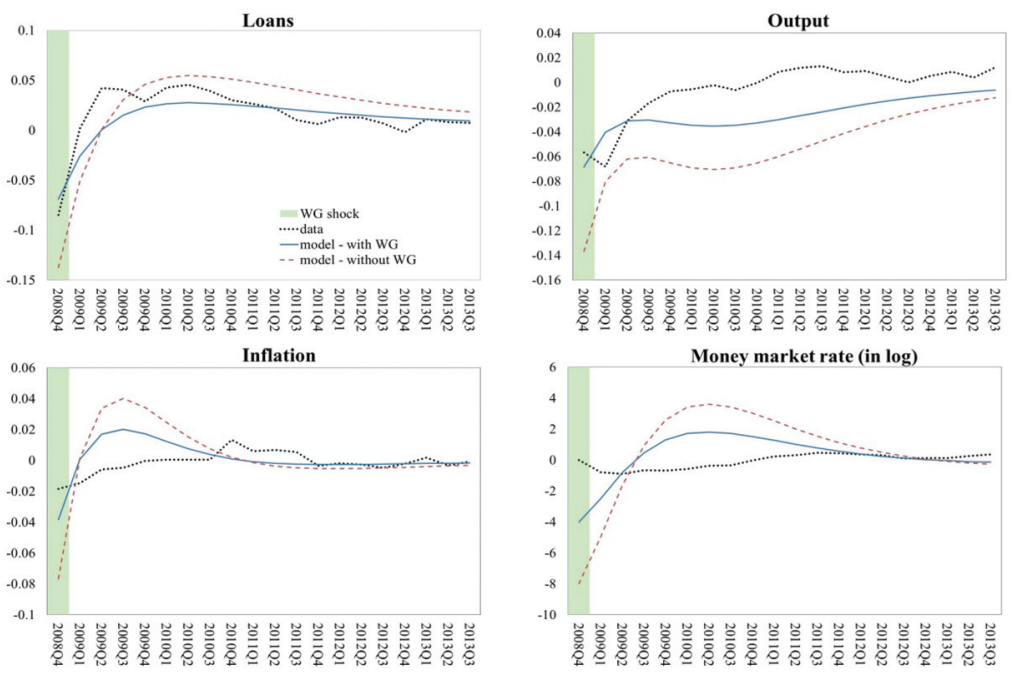

evidenced inflation below trend and low money market interest rates. These stylized facts suggest that a demand shock has played a prominent role in this period, in line with the findings of Le et al. (2014). The current paper augments these findings by considering a negative intermediation shock (i.e., a positive markup shock on lending interest rates) that occurred in 2008:Q4, large enough to trigger the quantitative policy tools of the $\mathrm{PBoC}$. The model is again solved up to first-order approximation with the help of the Dynare MATLAB toolbox (see Adjemian et al. 2014), and the computation of impulse responses with occasionally binding constraints is implemented with the OccBin toolkit (see Guerrieri and Iacoviello 2015).

The results of impulse response analysis are summarized in figure 4. We first analyze the no-window-guidance case, as a baseline on top of which window guidance operates. The increase in spreads induces higher lending rates and a decline in credit activity, while policy interest rates and money market rates decline on impact. The negative trend on investment drives the economy into a deep recession. Consumption also reacts negatively, reflecting lower income, combined with higher interest rates. Inflation initially declines to 
equilibrate markets, but then remains above trend, following with a lag the elevated marginal costs associated with the higher cost of capital.

Since the shock is rather transitory, the lower bound on credit activity is binding only on impact. Nevertheless, the entire transition path is affected by the presence of window guidance. Lending rates are lower relative to the no-window-guidance scenario to keep credit above the equilibrium transition path. Favorable financing conditions for firms stoke recovery through improved investment and income. A positive second-round effect through the monetary authority reaction function is realized. With decreased cost of capital, marginal costs are also lower in the window guidance case, leading to lower inflation rates. Weaker inflation pressures feed into lower policy interest rates that additionally stimulate recovery.

The numerical results suggest that the monetary policy reaction should go beyond the simple Taylor rule. The alternative nonlinear Taylor rule with window guidance that differentiates between normal times and severe crisis has appealing properties. Window guidance helps the recovery through both investment and consumption without jeopardizing bank profits.

The tentative conclusion is that the window guidance policy instrument can make a helpful contribution to economic stabilization.

\subsection{Welfare Analysis}

A possible way to determine the amount of euphoria window guidance brings is welfare analysis. We adopt a practical approach when evaluating the implications of introducing window guidance as an additional monetary policy tool. Following Glocker and Towbin (2012), we append a traditional loss function $\mathcal{L}=E\left(a^{\pi} \hat{\pi}+a^{y} \hat{y}^{2}\right)$ with macroprudential concerns. Similarly to Rubio and CarrascoGallego (2014), we proxy financial-sector soundness by the variance of the stock of bank loans. Specifically, we assume that the PBoC's objective is to minimize the function

$$
\mathcal{L}^{f}=E\left(a^{\pi} \hat{\pi}^{2}+a^{y} \hat{y}^{2}+a^{b}{\widehat{b^{E}}}^{2}\right)
$$


where $\widehat{\pi}, \widehat{y}, \widehat{b}^{E}$ are the percentage deviations of inflation, output, and loans to firms and the parameters $a^{\pi}, a^{y}, a^{b}$ reflect the relative importance of the three components for the $\mathrm{PBoC}$.

The task at hand is to simulate a series of exogenous shocks to consumption, investment, and financial intermediation. We then obtain the trajectories of key endogenous variables in response to these shocks with and without window guidance, and compare their variances. Window guidance is symmetric: it kicks in when borrowing deviates more than 1.5 percent from its steady-state value 21

In order to broaden our understanding of the effectiveness of window guidance practices in China, we extend our welfare analysis by constructing efficient policy frontiers in the spirit of Iacoviello (2005) and Levin, Wieland, and Williams (1999). The points on this frontier (also called Taylor curve) represent the tradeoffs that the authorities confront when they stabilize the economy - reaching lower variability of output may entail higher variance of inflation. The simulations below are based on the behavior of the model economy with the three shocks - consumption, investment, and intermediation - combined 22 The three policy objectives and their tradeoffs can be represented on three two-dimensional plots$(\sigma(y), \sigma(\pi)) ;\left(\sigma\left(b^{e}\right), \sigma(\pi)\right)$; and $\left(\sigma\left(b^{e}\right), \sigma(y)\right)$.

Next, we explain how the Taylor curves on the $(\sigma(y), \sigma(\pi))$-plane (with and without window guidance) are constructed. The other two graphs - on the $\left(\sigma\left(b^{e}\right), \sigma(\pi)\right)$-plane and on the $\left(\sigma\left(b^{e}\right), \sigma(y)\right)$ plane - are generated in the same way. For each set of weights $\left(a^{\pi}=\{0.1,0.2,0.3,0.4,0.5,0.6,0.7,0.8,0.9\}, a^{y}=1-a^{\pi}\right)$, we

\footnotetext{
${ }^{21}$ The model is simulated for 700 periods subject to a random sequence drawn from a normal distribution with appropriate variance. The first 100 periods are discarded to ensure that simulated statistics do not depend on the starting point. Then the entire simulation is repeated 300 times and the simulated time series are stacked together. Our decision to repeat a simulation of 700 periods 300 times is driven by the nature of the OccBin toolbox. The software employs a guess-andverify approach for choosing between the binding and nonbinding regimes, so the procedure becomes very time consuming in long simulations.

${ }^{22}$ We avoid constructing Taylor curves for each shock separately, since we are interested in the counterfactual behavior of the Chinese economy as a whole, when the possibilities of traditional monetary policy are exhausted. Moreover, looking at efficient policy frontiers for each shock would considerably lengthen the discussion without providing much further insight on the effectiveness of window guidance in China.
} 


\section{Figure 5. Conceivable Efficient Policy Frontiers}

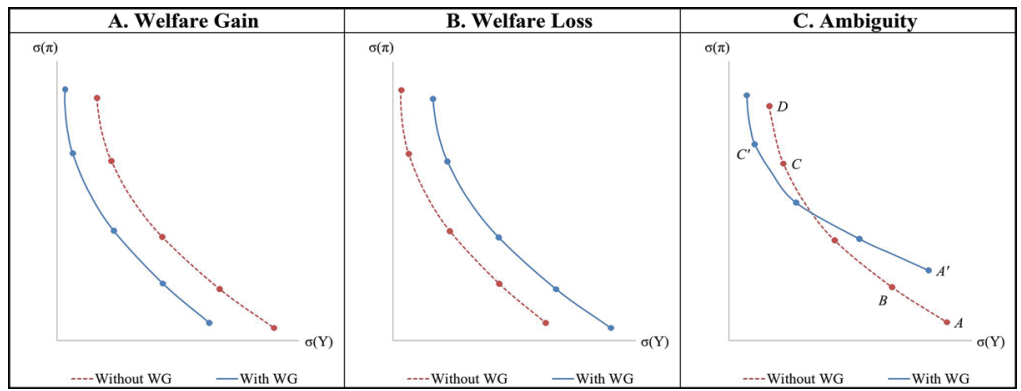

find the optimal response to inflation $\left(\phi^{\pi}\right)$ and plot the corresponding points on the $(\sigma(y), \sigma(\pi))$-plane. By adding window guidance at each of these nine points, we can measure the effect of introducing window guidance. Graphically, the position of the window guidance curve with respect to the original policy frontier is governed by the relative tradeoffs that window guidance offers at each of the original points. If window guidance can reduce output volatility by more than the reduction along the original curve, then window guidance is placed to the left of the traditional policy frontier and is welfare improving. Figure 5 displays the appearance of a hypothetical window guidance frontier in the case of welfare gains, welfare losses, and ambiguous results. In the first two panels the result is clear-all five points shift inward in figure $5 \mathrm{~A}$ and outward in figure $5 \mathrm{~B}$. In figure $5 \mathrm{C}$, however, each of the five dots moves up and left, meaning that window guidance decreases output volatility at the cost of more uncertain inflation outcomes. Hence, in point $A$ the tradeoff offered along the no-window-guidance schedule (point $B$ ) is superior to $A^{\prime}$. On the contrary, in point $C$ window guidance offers a better tradeoff (point $C^{\prime}$ ) than movement to point $D$ along the no-window-guidance policy frontier.

Figure $6 \mathrm{~A}$ demonstrates that window guidance can stabilize fluctuation of output and prices beyond the conduct of standard monetary policy, since the window guidance curve lies to the left of the original frontier. We construct a policy frontier on the $\left(\sigma\left(b^{e}\right), \sigma(\pi)\right)$ plane by finding the optimal response to inflation $\left(\phi^{\pi}\right)$ for each weight pair $\left(a^{b}, a^{\pi}\right)$. Again, the curve with window guidance is constructed by adding window guidance policy at each point on the 
Figure 6. Model-Based Efficient Policy Frontiers

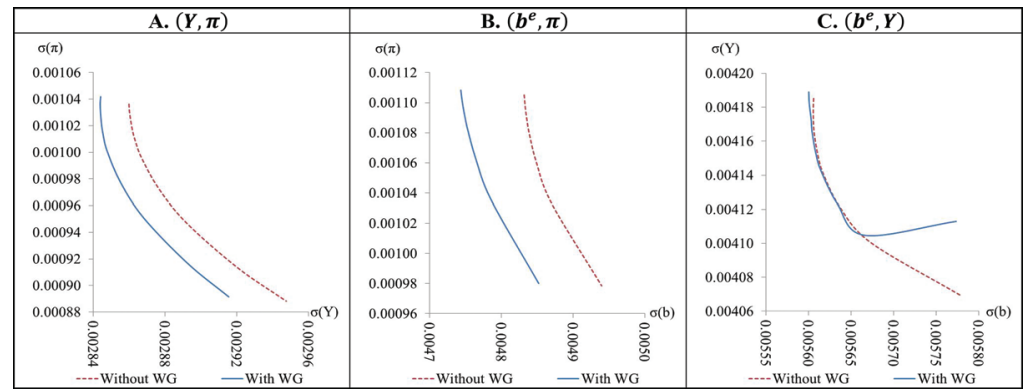

original frontier. Since the new schedule in figure $6 \mathrm{~B}$ lies to the left of the original one, we conclude that window guidance can potentially improve the economic outcome beyond the one achievable by a standard monetary policy rule. In constructing the policy frontier on the $\left(\sigma\left(b^{e}\right), \sigma(y)\right)$-plane in figure $6 \mathrm{C}$, we adopt a slightly different approach. Instead of changing the optimal response to inflation $\left(\phi^{\pi}\right)$ for each weight pair $\left(a^{b}, a^{y}\right)$, we vary $\phi^{y}$ optimally with the different values of $\left(a^{b}, a^{y}\right)$. The reason behind this choice is that the tradeoff between the variance of output and bank loans is much more pronounced when $\phi^{y}$ is the argument that minimizes the loss function. Again, the curve with window guidance is constructed by adding window guidance policy at each point on the original frontier. The new schedule crosses the original one, indicating that there is not a clear-cut answer as to whether window guidance is improving welfare. When bank loans are more volatile, window guidance is not efficient. A better tradeoff along the original policy frontier is available $-\sigma\left(b^{E}\right)$ is reduced by more, while $\sigma(y)$ increases by less than if window guidance is introduced at the point of high volatility of loans. This result can be rationalized as follows. When loans are more volatile, then window guidance is binding more often and for longer periods. That entails more distortions in interest rates and, consequently, real activity - consumption and investment. Output becomes more volatile, and constraining loan dynamics through the occasionally binding constraint becomes very costly. The alternative, i.e., changing the Taylor coefficient $\phi^{y}$, offers a better tradeoff, since the slope is quite flat at that part of the original policy frontier 
(due to the convex shape of the curve). No such result is present on the $\left(\sigma\left(b^{e}\right), \sigma(\pi)\right)$-plane, since inflation is less affected than output by the distortions that window guidance creates.

The evidence presented above brings a modicum of clarity to the polarized debate on the efficiency of window guidance. Altogether, the impulse response functions and the efficient policy frontiers for a combined demand, investment, and financial intermediation shock demonstrate that the addition of nonlinear window guidance policy may improve policy efficiency and welfare.

The reservation must be made, however, that our modeling framework analyzes business cycle dynamics and stabilization in a first-best environment. The reason for this is that we do not aim to model and evaluate the effect of financial market reforms in China. Unlike our paper, for example, Song, Stroesletten, and Zilibotti (2011) have studied a heterogeneous second-best environment with contractual and financial market imperfections. State-owned firms are less productive but have full access to the credit market. Entrepreneurial private firms are more productive but face credit constraints. In a comparable manner, Liu, Wang, and Xu (2017) have analyzed the relaxation of interest rate controls in China in a second-best environment. The ambiguous and varied quantitative conclusion is that interest rate liberalization improves capital allocation within each sector but exacerbates misallocations across sectors. What is the likely effect of such financial market distortions upon the efficient policy frontiers presented above? Since most of the window guidance loans are absorbed by state-owned firms, the existing misallocation in the capital markets would be reinforced. Recently, Cao et al. (2018) have studied the consequences of monthend quantity lending targets for Chinese bank managers. Using data from two banks, one state-owned and the other partially privatized, they show that in their pursuit of increased lending to meet targets, credit risk has become a secondary consideration. On that account, the use of window guidance leads to concerns about the longer-term sustainability of China's economic boom.

\section{Window Guidance-Panacea or Curse?}

Window guidance is an administrative measure for monetary policy implementation. Given that China's banking system is dominated by 
large state-owned banks, the PBoC's window guidance has shown itself to be very effective in short-run stabilization. However, over the long run, it generates distortions and inefficiency. Window guidance is much easier to implement in conditions of excess liquidity, a common situation in China, where the banking system often carries excess reserves. In terms of allocation of credit or addressing misallocation of credit among different sectors, window guidance is also a direct measure, and therefore quite effective. Given that it overrides the market mechanism, it could lead to inconsistency and structural imbalance in the long run. Some of the overcapacity problems in the Chinese economy could well be the consequence of the past window guidance policy. The $\mathrm{PBoC}$ has used window guidance as a supplementary policy to regular monetary policy and fiscal policy. In a transition economy with substantial distortions, administrative measures such as window guidance can help partly correct distortion effects, but in the long run, structural and institutional reforms are needed to create a smoothly functioning market economy and allow market incentives to work. Thus, window guidance should be used sparingly to correct market failures, as well as in times of crisis to avoid hard landings or dark corners 23

China's window guidance policy provides several lessons for policymakers. The Chinese economy has gone through boom-and-bust cycles since the launch of reforms in early 1980s. Whether the issue was overheating, recession, or structural imbalances such as overcapacity in some sectors, window guidance was a go-to tool to affect bank lending.

The first lesson is that excessive encouragement of banking lending may prevent the economy from falling into deep recession, but

\footnotetext{
${ }^{23}$ According to Zilibotti (2017), even though the window-guidance-type stimulus package of 2008-09 helped China to take shelter from the Great Recession, it significantly distorted the development trajectory of the Chinese economy. The investment boom strengthened investment-led growth and delayed the transition to an innovation-led growth. The easy credit was not channeled to innovative startup businesses but rather favored large firms in traditional sectors and local governments. The growth-enhancing decline in the share of SOEs was reversed. Furthermore, the credit-induced boom led to excess capacity in many key sectors, which calls for another set of costly state interventions to shut down unproductive plants and support workers with safety nets in the afflicted areas.
} 


\section{Figure 7. Private Non-financial Loans and Financial Crises in Selected Economies}

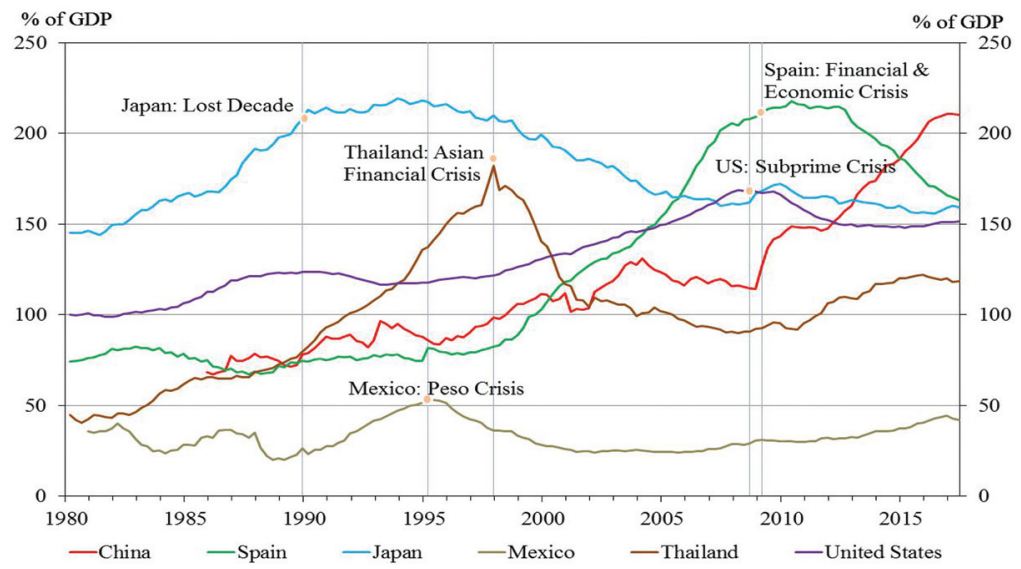

Sources: Bank for International Settlements and authors' calculations.

it can also lead to high levels of debt that may be unsustainable. In 2008-09 at the height of the global financial crisis, the Chinese government implemented a 4-trillion-yuan fiscal stimulus package and encouraged banks to lend another 10 trillion yuan to finance "infrastructure" projects. The drastic increase of bank credit caused the credit-to-GDP ratio to soar, and tolerated exuberant lending practices. Even after the government's efforts to deleverage both the government and private sectors, overall debt levels in China are quite high and still rising.

In international comparison, China's debt has reached an alarming level. By mid-2017, China's private nonfinancial debt exceeded 200 percent of GDP, a level close to the peak levels of Japan and Spain just before their crises (figure 7) - and only slightly lower than in Japan during the onset of the lost decade. Among major economies, only China attempted to sustain a high pace of credit growth after the global financial crisis. The recent surge in China's credit growth since 2012 partly reflects the PBoC's failure to curb lending and remaining reliant on bank credit to support the economic growth through window guidance policy. Overreliance on 
window guidance, subsequently, has ratcheted up corporate debt to unsustainable levels 24

As we have seen, window guidance can correct misallocation of credit in a distorted economy. But it can also create further distortion. To optimize the bank credit structure, the PBoC introduced a differentiated window guidance policy approach in 2012 . This nuanced approach allows the $\mathrm{PBoC}$ to rein in bank lending in overcapacity sectors, while encouraging the banks to step up policy lending to the real economy. Credit growth in overcapacity sectors (e.g., cement, coal, steel, glass, real estate, etc.) decreased to single digits in the 2011-15 period (in 2015, the growth rate was 1.5 percent, 2.4 percentage points below the 2014 figure), while the growth in total loans exceeded 10 percent in the same period. In the first half of 2016, loans to these sectors showed negative growth 25 This development suggests that more selective use of window guidance may help improve bank credit structure and that steering window guidance in a targeted and effective manner may help with overcapacity problems. However, it is not easy a priori for the $\mathrm{PBoC}$ to say how much it needs to tighten credit or deleverage in the overcapacity sector, or how much it should encourage banks to lend to policy sectors such as the high-tech sector or small and medium-sized enterprises. Window guidance ultimately is a crude measure and may lead to dynamic inefficiency. Some sectors appearing to suffer from overcapacity during a downturn may face capacity constraints when the economy recovers.

Furthermore, with the ongoing process of financial liberalization, the effectiveness of window guidance gradually wears off. China's financial system is still dominated by banks, but its stock and bond markets have grown very fast, not to mention the shadow banking sector. Banks are also increasingly subject to market discipline and profit pressure. All these developments dilute the effectiveness

\footnotetext{
${ }^{24}$ The Bank for International Settlements (2016) raised the red flag of debt overhang when it reported a "credit gap" of 30 percent for China. Drehmann and Tsatsaronis (2014) assert that the credit gap is a reliable and robust early-warning indicator of impending banking crises.

${ }^{25}$ The information on growth rates of lending to overcapacity sectors was taken from Chinese-language news reporting on credit growth. For instance, see http://cn.reuters.com/article/pboc-fin-cost-idCNKCS0UT0OY and http://www.gov.cn/xinwen/2016-07/15/content_5091793.htm.
} 
of window guidance measures that are focused solely at traditional banks (Fukumoto et al. 2010). Thus, while window guidance may help the $\mathrm{PBoC}$ in fulfilling its multiple policy objectives, its use (if at all) must be highly restrained and applied only in exceptional circumstances. The overuse of window guidance leads to such problems as overshooting monetary targets and misallocation of credit. It is very difficult to implement the "quantity-based" policy within appropriate targets, particularly in the long term. It leaves the $\mathrm{PBoC}$ with a tradeoff between short-term stabilization and deep structural reform.

\section{Conclusions}

The DSGE model presented here provided insights into the pros and cons of the nonstandard monetary policy tool, window guidance, in China. Policymakers should find our modeling exercise worthwhile, and it serves as a serious starting point in the current discussion on overhauling Chinese monetary policy.

Over the past decades, a defining feature of the PBoC's policy is its focusing on the quantity, not the price, of money. This feature has slowly changed, bringing China closer to the norm in advanced economies, an essential transition for an increasingly complex economy. It is confirmed by the IMF. In its annual Article IV review of China's economy (IMF 2017a), the IMF passed a tentative verdict (p. 29): "The conduct of monetary policy increasingly resembles a standard interest-rate-based framework." The IMF also pointed out that this new approach would be strengthened by formally acknowledging this new price-based framework and dropping quantitative targets. In a response, the Chinese authorities stated that "(it) is premature to drop monetary aggregate targets ... (and) to refer explicitly to the 7-day repo as the policy rate" (p. 29). The gradual monetary policy shift is work in progress, however, the precise outcome of which is uncertain. It is therefore safe to assume that window guidance remains a policy instrument as evidenced from $\mathrm{PBoC}$ monetary policy reports. Here, we applied a DSGE modeling approach enriched by a nonstandard window guidance toolkit to shed light on the efficacy of window guidance. While the DSGE framework suggests that window guidance can help provide additional monetary 
policy stimulus, our welfare analysis shows that the window guidance toolkit could have a negative welfare effect in certain cases.

Finally, we are aware that a number of potential extensions could affect the findings reported in this paper. An interesting extension to this analysis of window guidance would be to incorporate recurring, endogenous financial booms and busts. The financial cycle develops over time and eventually collapses in a costly bust. The optimal monetary policy then reflects the tradeoff between the short-run macroeconomic stabilization and the longer-run benefits of stabilizing the financial cycle. One might expect that occasional nonstandard window guidance policy is then justified because the policy also smooths the financial cycle. In doing so, the central bank reduces the probability and severity of a financial bust. In sum, occasional window guidance policies might support a shift away from narrow price stability orientation to a more inclusive joint price and financial stability orientation.

\section{References}

Adjemian, S., H. Bastani, F. Karamé, M. Juillard, J. Maih, F. Mihoubi, G. Perendia, J. Pfeifer, M. Ratto, and S. Villemot. 2014. "Dynare: Reference Manual, Version 4." Dynare Working Paper No. 1.

Angrick, S., and N. Yoshino. 2018. "From Window Guidance to Interbank Rates - Tracing the Transition of Monetary Policy in Japan and China." BOFIT Discussion Paper No. 4/2018, Bank of Finland.

Bank for International Settlements. 2016. BIS Quarterly Review (September).

Bernanke, B. S., and V. R. Reinhart. 2004. "Conducting Monetary Policy at Very Low Short-Term Interest Rates." American Economic Review 94 (2): 85-90.

Blanchard, O. 2014. "Where Danger Lurks." Finance and Development (International Monetary Fund) 51 (3): 28-31.

Brüggemann, R., and J. Riedel. 2011. "Nonlinear Interest Rate Reaction Functions for the UK." Economic Modelling 28 (3): 1174-85.

Buera, F. J., J. P. Kaboski, and Y. Shin. 2011. "Finance and Development: A Tale of Two Sectors." American Economic Review 101 (5): 1964-2002. 
Cao, Y., R. Fisman, H. Lin, and Y. Wang. 2018. "Target Setting and Allocative Inefficiency in Lending: Evidence from Two Chinese Banks." NBER Working Paper No. 24961.

Chang, C., Z. Liu, and M. Spiegel. 2015. "Capital Controls and Optimal Chinese Monetary Policy." Journal of Monetary Economics 74 (September): 1-15.

Chang, C., Z. Liu, M. Spiegel, and J. Zhang. 2016. "Reserve Requirements and Optimal Chinese Stabilization Policy." Working Paper No. 2016-10, Federal Reserve Bank of San Francisco.

Chen, K., J. Ren, and T. Zha. 2018. "The Nexus of Monetary Policy and Shadow Banking in China." American Economic Review 108 (12): 3891-3936.

Cukierman, A., and A. Muscatelli. 2008. "Nonlinear Taylor Rules and Asymmetric Preferences in Central Banking: Evidence from the United Kingdom and the United States." B.E. Journal of Macroeconomics 8 (1): 1-29.

Dai, L., P. Minford, and P. Zhou. 2015. "A DSGE Model of China." Applied Economics 47 (59): 6438-60.

Drehmann, M., and K. Tsatsaronis. 2014. "The Credit-to-GDP Gap and Countercyclical Capital Buffers: Questions and Answers." BIS Quarterly Review (March): 55-73.

Fernald, J., M. M. Spiegel, and E. T. Swanson. 2014. "Monetary Policy Effectiveness in China: Evidence from a FAVAR Model." Journal of International Money and Finance 49 (Part A): 83103.

Fukumoto, T., M. Higashi, Y. Inamura, and T. Kimura. 2010. "Effectiveness of Window Guidance and Financial Environment in Light of Japan's Experience of Financial Liberalization and a Bubble Economy." Bank of Japan Review No. 10-E-4.

Gerali, A., S. Neri, L. Sessa, and F. M. Signoretti. 2010. "Credit and Banking in a DSGE Model of the Euro Area." Journal of Money, Credit and Banking 42 (s1): 107-41.

Glocker, C., and P. Towbin. 2012. "Reserve Requirements for Price and Financial Stability: When Are They Effective?" International Journal of Central Banking 8 (1, March): 65-113.

Guerrieri, L., and M. Iacoviello. 2015. "OccBin: A Toolkit for Solving Dynamic Models with Occasionally Binding Constraints Easily." Journal of Monetary Economics 70 (March): 22-38. 
Hachem, K., and Z. Song. 2016. "Liquidity Regulation and Unintended Financial Transformation in China." NBER Working Paper No. 21880.

He, D., H. Wang, and X. Yu. 2015. "Interest Rate Determination in China: Past, Present, and Future." International Journal of Central Banking 12 (4, December): 255-77.

Hsieh, C., and P. J. Klenow. 2009. "Misallocation and Manufacturing TFP in China and India." Quarterly Journal of Economics 124 (4): 1403-48.

Iacoviello, M. 2005. "House Prices, Borrowing Constraints, and Monetary Policy in the Business Cycle." American Economic Review 95 (3): 739-64.

International Monetary Fund. 2017a. "2017 Article IV Consultation - Staff Report for the People's Republic of China." Country Report No. 17/247.

- 2017b. "People's Republic of China - Selected Issues." Country Report No. 17/248.

Jeanne, O. 2013. "Capital Account Policies and the Real Exchange Rate." In NBER International Seminar on Macroeconomics 2012, ed. F. Giavazzi and K. D. West, 7-42 (chapter 1). Chicago: University of Chicago Press.

Lamarche, J.-F., and Z. Koustas. 2012. "Estimation of a Nonlinear Taylor Rule Using Real-Time US Data." Studies in Nonlinear Dynamics and Econometrics 16 (5): 1-25.

Lardy, N. 2005. "Exchange Rate and Monetary Policy in China." Cato Journal 25 (1, Winter): 41-47.

Le, V. P. M., M. Kent, D. Meenagh, and P. Minford. 2014. "Banking and the Macroeconomy in China: A Banking Crisis Deferred?" Open Economies Review 25 (1): 123-61.

Levin, A., V. Wieland, and J. C. Williams. 1999. "Robustness of Simple Monetary Policy Rules under Model Uncertainty." In Monetary Policy Rules, ed. J. B. Taylor, 263-99 (chapter 6). Chicago: University of Chicago Press.

Li, B., and Q. Liu. 2017. "On the Choice of Monetary Policy Rules for China: A Bayesian DSGE Approach." China Economic Review 44 (July): 166-85.

Liu, Z., P. Wang, and Z. Xu. 2017. "Interest-Rate Liberalization and Capital Misallocation. Working Paper No. 2017-15, Federal Reserve Bank of San Francisco. 
People's Bank of China. "Quarterly Monetary Policy Report." Various Issues.

Romer, C. D., and D. H. Romer. 1989. "Does Monetary Policy Matter? A New Test in the Spirit of Friedman and Schwartz." NBER Macroeconomics Annual 1989, Vol. 4, ed. O. J. Blanchard and S. Fischer, 121-84 (chapter 3). MIT Press.

- 2004. "A New Measure of Monetary Shocks: Derivation and Implications." American Economic Review 94 (4): 1055-84.

Rubio, M., and J. A. Carrasco-Gallego. 2014. "Macroprudential and Monetary Policies: Implications for Financial Stability and Welfare." Journal of Banking and Finance 49 (December): 326-36.

Schroder, C., and S. Yitzhaki. 2017. "Revisiting the Evidence for Cardinal Treatment of Ordinal Variables." European Economic Review 92 (February): 337-58.

Song, Z., K. Stroesletten, and F. Zilibotti. 2011. "Growing Like China." American Economic Review 101 (1): 196-233.

Thimme, J. 2017. "Intertemporal Substitution in Consumption: A Literature Review." Journal of Economic Surveys 31 (1): 226-57. Zhang, L. 2016. "Rebalancing in China - Progress and Prospects." IMF Working Paper No. 16/183.

Zhang, X., and Z. Ji. 2012. China Monetary Policy. Beijing: Chinese Financial Press.

Zilibotti, F. 2017. "Growing and Slowing Down Like China." Journal of the European Economic Association 15: 943-88. 